Teresa WOLIŃSKA*

\title{
ELITY CHRZEŚCIJAŃSKIE WOBEC ISLAMU (VII-X WIEK) **
}

Trudno w dziejach znaleźć wydarzenia, które byłyby równie przełomowe jak narodziny islamu i ekspansja arabska. Nie od razu dostrzeżono ich znaczenie. Najazd arabski nie był wszak pierwszym i jedynym, jaki dotknął Bliski Wschód. Zaledwie kilkanaście lat wcześniej Syria, Palestyna i Egipt doświadczyły okupacji perskiej. Dlatego inwazja arabska nie była początkowo postrzegana jako coś wyjątkowego. $Z$ kolei islam nie od razu został zidentyfikowany jako nowa, odrębna religia. Nie zdawano sobie sprawy z jego atrakcyjności i siły pozyskiwania nowych wyznawców.

To, co nie było oczywiste dla współczesnych, dziś nie może budzić większych wątpliwości. Pojawienie się islamu było przełomem w wielu wymiarach. Religijnym, gdyż narodziło się wyznanie, które okazało się atrakcyjne dla milionów ludzi na ogromnym obszarze, obejmującym już w pierwszym wieku swego istnienia terytoria na trzech kontynentach. Politycznym, bowiem zapoczątkowało podział świata śródziemnomorskiego. Gospodarczym, gdyż cesarstwo utraciło najbogatsze prowincje, na dodatek będące źródłem zaopatrzenia stolicy. Kulturowym i językowym, odcinając od Bizancjum obszary zamieszkane przez ludność mówiącą po syryjsku i koptyjsku, a następnie stopniowo upowszechniając na nich język arabski. O przełomowym znaczeniu podbojów arabskich przekonany był już Henri Pirenne (23 XII 1862 - 25 X 1935), dla którego wyznaczały one prawdziwe przejście od starożytności do średniowiecza ${ }^{1}$. Chociaż jego teza była krytykowana i obecnie nie jest w całości akceptowana, nie sposób nie uznać niektórych argumentów francuskiego badacza.

W niniejszym artykule podejmę próbę rozpoznania reakcji elit chrześcijańskich na pojawienie się u granic cesarstwa, a potem na odebranych mu terytoriach, nowej religii monoteistycznej.

* Dr hab. Teresa Wolińska, prof. UŁ - profesor nadzwyczajny w Katedrze Historii Bizancjum Uniwersytetu Łódzkiego w Instytucie Historii na Wydziale Filozoficzno-Historycznym; e-mail: t.wolinska@wp.pl.

** Niniejszy artykuł powstał w ramach grantu NCN (projekt 2012/04/M/HS3/00564: Bizancjum i Arabowie. Spotkanie cywilizacji VI - VIII wieku).

${ }^{1}$ Por. H. Pirenne, Mahomet et Charlemagne, Paris 1937. 
Podstawa źródłowa takich badań jest zróżnicowana zarówno pod względem językowym, jak i typologicznym. Składają się na nią zarówno teksty stricte historyczne, jak i literatura apokaliptyczna i polemiczna². Wśród tych pierwszych wymienić trzeba m.in. kroniki Teofanesa Wyznawcy (ok. 760$818)^{3}$, Sebeosa (VII w.) ${ }^{4}$, Jana z Nikiu (VII wiek) ${ }^{5}$. Druga grupa reprezentowana jest przez tekst nawróconego Żyda (Doctrina Jacobi nuper baptizati) ${ }^{6}$, Apokalipsę Pseudo-Efrema ${ }^{7}$, Apokalipsę Pseudo-Metodego ${ }^{8}$, Wizję Daniela ${ }^{9}$,

2 Jak to ujął Demetrios J. Constantelos (The Moslem Conquest of Near East as Reveated in Greek Sources of the VII th and the VIII th Century, „Byzantion” 42 (1972) 325) mamy do czynienia z tekstami opisującymi ekspansję arabską i traktatami opisującymi relacje między zwycięskimi Arabami a ludnością podbitą, wreszcie pismami teologicznymi i apologetycznymi, odnoszącymi się do islamu, jako religii.

${ }^{3}$ Por. Theophanes Confessor, Chronographia, ed. C. de Boor, vol. 1, Lipsiae 1883 (= Theophanes, Chronographia, rec. I. Classenus, vol. 1, CSHB 32, Bonnae 1839). Teofanesowi zawdzięczamy wiele informacji o walkach bizantyńsko-arabskich, które nie interesują nas w tym miejscu. Jednak przy okazji odnotowywania śmierci Mahometa, którą błędnie datował na rok 622, podał szereg istotnych informacji o islamie, por. Theophanes, Chronographia, CSHB 32, 511, 5 - 514, 6.

${ }^{4}$ Por. Sebeos, Historia de Heraclio, traduite de l'arménien et annotée par F. Macler: Histoire d'Héraclius par l'évêque Sébeos, Paris 1904.

${ }^{5}$ Por. Joannes Niciensis, Chronica, translated from Zotenberg's Ethiopic text by R.H. Charles: The Chronicle of John, bishop Nikiu, Text and Translation Society, London 1916.

${ }^{6}$ Por. Doctrina Jacobi nuper baptizati, éd. et trad. par V. Deroche, commentaire par G. Dagron : L'Enseignement de Jacob, nouvellement baptisé, „Travaux et Mémoires” 11 (1991) 208-210; J. Flori, L'Islam et la fin des temps. L'interpretation prophetique des invasions musulmenes dans la chrétienté médiévale, Paris 2007, 123-127.

${ }^{7}$ Por. Ephraem, Sermo de fine mundi, hrsg. und übersetzt von E. Beck: Des heiligen Ephraem des Syrers Sermones 3, CSCO 321. Scriptores Syri 139, Louvain 1972, 60-71 (tekst) i 79-94 (przekład), lub hrsg. und mit Anmerkungen und Abhandlungen begleitet von C.P. Caspari: Briefe, Abhandlungen und Predigten aus den zwei letzten Jahrhunderten des kirchlichen Altertums und dem Anfang des Mittelaters, Christiania [Oslo] 1890, 208-220 (przekład łaciński); zob. też Flori, L'Islam et la fin des temps, s. 132-133, nota. 1.

${ }^{8}$ Istnieją różne wersje tej apokalipsy: syryjska, grecka, łacińska, starocerkiewnosłowiańska. Pierwszą z wymienionych wydał F.J. Martínez: Apocalypse syriaque du Pseudo-Méthode, éd. et transl. par F.J. Martínez, w: Eastern Christian Apocaliptic in the Early Muslim Period: PseudoMethodius and Pseudo-Athanasius, (Phil. Diss.), part 1, Washington 1985, 58-92 (tekst) i 122-157 (przekład). Edycję wersji greckiej i łacińskiej z przekładem na język angielski znajdziemy w: Apocalypse Pseudo-Methodius, ed. and transl. by B. Garstad, Dumbarton Oaks Medieval Library 14, Cambridge (Mass.) - London 2012, 2-71 (wersja grecka), 74-141 (wersja łacińska). Polski przekład wersji syryjskiej: Apokalipsa Pseudo-Metodego, tłum. A. Tronina, w: Apokryfy syryjskie, red. M. Starowieyski, Pisma Apokryficzne 6, Kraków 2011, 212-238. Por. P.J. Alexander, The Byzantine Apocalyptic Tradition, Berkeley - Los Angeles 1985, 13-60; Flori, L'Islam et la fin des temps, s. 133-141; G. Reinink, Pseudo-Methodius: A Concept of History in Response to the Rise of Islam, w: The Byzantine and Early Islamic Near East, Papers of the First Workshop on Late Antiquity and Early Islam, ed. A. Cameron - L.I. Conrad - G.R.D. Kind, Studies in Late Antiquity and Early Islam 1, t. 1, Princeton 1992, 149-187.

${ }^{9}$ Por. Visio Danielis (slavice), ed. by P.A. Lavrov: Apokrifičeskije teksty, Sbornik Otdeleniya russkogo yazyka i slovesnosti Imperatorskoi Akademii Nauk 67, Moskva 1899, thum. angielskie 
Apokalipse Andrzeja Szalonego († 936) $)^{10}$, teksty Pseudo-Atanazego (IV-VI w. $)^{11}$, Anastazego Synaity († ok. 700 $)^{12}$ i innych. Spośród innych tekstów warto wspomnieć dzieło Pseudo-Nila z Synaju (IX w.), zaliczone przez Vasiliosa Christidesa do kategorii „hagiographical romances”13. Osobna grupe stanowi korespondencja (prawdziwa lub fikcyjna) oraz relacje z debat między chrześcijanami i muzułmanami. Te ostatnie zapoczątkowuje zapis rozmowy jakobickiego patriarchy Antiochii (= syryjskiego patriarchy Antiochii) Jana II (= Jan z Sedre: czasem zwany Janem I; $\uparrow$ 648, patriarcha od 631$)^{14}$ z Amrem ibn Al-Asem (ok. 585 - ok. 665) ${ }^{15}$. Do gatunku tego należy też odpowiedź, jakiej cesarz Leon III (ok. 680 - 18 VI 741, cesarz od 25 III 717) udzielić miał Umarowi II (682-720, kalif od 717) oraz list Aretasa z Cezarei Kapadockiej

P.J. Alexander: Vision of the Prophet Daniel on the Emperors and the Last Days and the End of the World, w: The Byzantine Apocalyptic Tradition, s. 65-72.

${ }^{10}$ Por. Andreas Salos, Apocalypsis, ed. and translated by L. Rydén: The Andreas Salos Apocalypse, DOP 28 (1974) 197-261, lub thum. angielskie w: Alexander, The Byzantine Apocalyptic Tradition, s. 123-125.

${ }^{11}$ Por. Pseudo-Athanasius, Apocalypsis, éd. et transl. par F.J. Martínez: Apocalypse sahidique du Pseudo-Athanase, w: Eastern Christian Apocaliptic, part 2, s. 285-411 (tekst koptyjski i arabski Apokalipsy), s. 462-555 (przekład); zob. Flori, L'Islam et la fin des temps, s. 141-144.

${ }^{12}$ Oprócz dzieł teologicznych pod imieniem Anastazego zachowały się trzy (A, B, C) korpusy zbiorów opowieści o cudach (Narrationes). Dwa pierwsze (z inną numeracją) zostały wydane przez François Nau (Le texte grec des récits du moine Anastase sur les saints Pères du Sinaï, OC 2:1902, 58-87; tenże, Le texte grec des récits utiles à l'âme d'Anastase (Sinaïte), OC 3:1903, 56-85). F. Nau wydał też fragmenty C 4 i C 11 oraz przełożył te wydane fragmenty na język francuski (Le récits inédites du moine Anastase, „Revue de l'Institut Catholique de Paris” 1:1902, 1-26; 2:1902, 110151). Pozostałe fragmenty są rozproszone w innych wydaniach lub pozostają wyłącznie w manuskryptach. Bernard Flussin (Démons et Sarrasins. L'auteur et le propos des Diègémata stèriktika d'Anastase le Sinaïte, „Travaux et Mémoires” 11:1991, 395) broni tezy, że wszystkie zachowane korpusy wyszły spod pióra jednego autora. Szerzej na ten temat zob. Flussin, Démons et Sarrasins, s. 381-408; SWP 33-34.

${ }^{13}$ Por. V. Christides, Once again the „Narrations” of Nilus Sinaiticus, „Byzantion” 43 (1973) 40. Kiedyś sądzono, że Narrationes napisał Nil z Ancyry, ale obecnie odrzuca się tę identyfikację i datuje się tekst na IX w., chociaż zawiera on wiele wzmianek o wcześniejszych wydarzeniach, dlatego używa się imienia Pseudo-Nil, zob. History and Hagiography form the Late Antique Sinai. Including Translations of Pseudo-Nilus' ,Narrationes”, Ammonius' ,, Report of the Slaughter of the Monks of Sinai and Rhaithou” and Anastasius of Sinai's „,Tales of the Sinai Fathers”, ed. D.F. Craner - S. Brock - R.M. Price - K. van Blandel, Translated Texts for Historians 53, Liverpool 2010, 74-75.

${ }^{14}$ Por. F. Nau, Appendice, w: Colloquium Joannis patriarchae cum amero Agarenorum, éd. et transl. par F. Nau: Un colloque du patriarche Jean avec l'émir des Agaréens et faits divers des annés 712 à 716, ,Journal Asiatique” 11 (1915) nr 5, 268-271.

${ }^{15} \mathrm{O}$ Amrze ibn Al-Asie, por. F. Nau, Introduction, w: Un colloque du patriarche Jean, s. 230232. Przypisuje mu się odbycie dyskusji religijnych z cesarzem Konstansem [zwanym też Konstantynem IV Pogonatem] (7 XI 630 - 15 IX 668; cesarz od 641) w roku 638 i z patriarchą koptyjskim Beniaminem (ok. 590 - 16 I 662; patriarcha od 623) w roku 643; zob. także History of the Patriarchs of the Coptic Church of Alexandria, ed. B. Evetts, PO 1, fasc. 4, Paris 1948, 496-498. 
(ok. 860 - ok. 935) ${ }^{16}$. Podziały na poszczególne kategorie źródeł nie zawsze są ostre. Dla przykładu również Sebeos tłumaczył wydarzenia w kontekście apokaliptycznym i profetycznym ${ }^{17}$.

Temat niniejszego artykułu nie jest całkowicie nowy. Uczeni już od długiego czasu interesują się relacjami chrześcijańsko-islamskimi i w ich badaniach pojawia się kwestia reakcji Bizantyńczyków na nowe wyzwanie. Wśród tych autorów, których prace wnoszą istotny wkład dla zrozumienia zachodzących procesów, wymienić należy m.in. Armanda Abela (11 VI 1903 - 31 V 1973) ${ }^{18}$, Johna Meyendorffa (17 II 1926 - 22 VII 1992) ${ }^{19}$, Sebastiana Brocka ${ }^{20}$, Jeana Flori $^{21}$, Waltera E. Kaegiego ${ }^{22}$, Hugh Kennedy'ego ${ }^{23}$, Daniela J. Sahasa ${ }^{24}$, Alana Camerona ${ }^{25}$, Irfana Shahida ${ }^{26}$, Gerrita J. Reininka ${ }^{27}$, Michaiła Wasilijewicza

${ }^{16}$ Por. Arethas Caesariensis, Epistula ad ameram Damascenum, ed. L.G. Westerink: Arethae archiepiscopi Caesariensis scripta minora, vol. 1, Leipzig 1968, 233-245, lub P. Karlyn-Hayter: Arethas's Letter to the Emir at Damascus, „Byzantion” 29-30 (1959/1960) 293-302. Przekład francuski zamieszcza Armand Abel: La lettre polémique d'Arethas à l'émir de Damas, „Byzantion” 24 (1954) 355-370; zob. też Flori, L'Islam et la fin des temps, s. 144-146.

${ }^{17}$ Por. Sebeos, Historia de Heraclio, thum. Macler, s. 104-105. Zob. Flori, L'Islam et la fin des temps, s. 128-130.

${ }^{18}$ Por. Abel, La lettre polémique, s. 343-370.

${ }^{19}$ Por. J. Meyendorff, Byzantine Views of Islam, w: Arab-Byzantine Relations in Early Islamic Times, ed. M. Bonner, Ashgate 2004, 217-234 [pierwodruk: DOP 18 (1964) 113-132].

${ }^{20}$ Por. S. Brock, Syriac Vievs of Emergent Islam, w: tenże, Syriac Perspectives on Late Antiquity, Collected Studies Series 199, London 1984, 9-21; tenże, Syriac sources for seventh-century history, „Byzantine and Modern Greek Studies” 2 (1976) 17-36; tenże, Syriac Historical Writing: a Survey of the Main Sources, „Journal of the Iraqi Academy (Syriac Corporation)” 5 (1979/1980) 297-326 (= tenże, Studies in Syriac Christianity. History, Literature and Theology, Collected Studies Series 357, Aldershot 1992, 297-326).

${ }^{21}$ Por. nota 7.

${ }^{22}$ Por. W.E. Kaegi, Initial Byzantine Reactions to the Arab Conquest, w: The Expansion of the Early Islamic State, ed. F.M. Donner, The Formation of the Classical Islamic World 5, Aldershot 2008, 113-121 [pierwodruk: ChH 38 (1969) 139-149].

${ }^{23}$ Por. H. Kennedy, Wielkie arabskie podboje. Jak ekspansja islamu zmienia świat, thum. M. Wilk, Warszawa 2011.

${ }^{24}$ Por. D.J. Sahas, John of Damascus on Islam: the „Heresy of the Ishmailites”, Leiden 1972.

${ }^{25}$ Por. A. Cameron, The Literary Sources for Byzantium and Early Islam, w: La Syrie de Byzance à l'Islam: VII ${ }^{e}$-VIII ${ }^{e}$ siècles. Actes du Colloque international (Lyon - Paris, 11-15 septembre 1990), publiés par P. Canivet et J.-P. Rey-Coquais, Publications de l'Institut Français de Damas 137, Damas 1992, 3-14.

${ }^{26}$ Por. I. Shahid, Byzantium and the Arabs in the Sixth Century, t. I, cz. 1: Political and Military History, Washington 1995; tenże, Byzantium and the Arabs in the Sixth Century, t. I, cz. 2: Ecclesiastical History, Washington 1995; tenże, Byzantium and the Arabs in the Fifth Century, Washington 1989.

${ }^{27}$ Por. Reinink, Pseudo-Methodius: A Concept of History, s. 149-187; tenże, Political Power and Right Religion in the East-Syrian Disputation between a monk of Bēt Hālè and an Arab notable, w: The Encounter of Eastern Christianity with Early Islam, ed. E. Grypeou - D.R. Thomas - M. Swanson, The History of Christian-Muslim Relations 5, Leiden 2006, 153-169. 
Krivova $^{28}$, Sidneya H. Griffitha ${ }^{29}$. W Polsce zagadnienia te były przedmiotem zainteresowania m.in. Krzysztofa Kościelniaka ${ }^{30}$, Danuty Madeyskiej ${ }^{31}$, Michała Sadowskiego $^{32}$, Marcina Grodzkiego ${ }^{33}$ i Jana W. Żelaznego ${ }^{34}$. Inne prace polskich autorów, poświęcone światu muzułmańskiemu, dotyczą okresu późniejszego lub innych zagadnień.

W badaniach natrafiamy na poważne trudności metodologiczne. Niełatwo jest rozróżnić emocje wywołane najazdem jako takim, od spowodowanych uświadomieniem sobie zagrożenia konkurencją ze strony nowej religii uniwersalistycznej. Podobnie trudna jest odpowiedź na pytanie, co to jest elita i kogo do niej, w realiach VII-X w., należy zaliczyć? Jeszcze większym wyzwaniem jest zakreślenie granic terytorialnych badań. Chrześcijanie żyli nie tylko pod panowaniem bizantyńskim, ale i perskim. Jedni i drudzy wskutek podboju znaleźli się w granicach kalifatu. W tej sytuacji trudno jest ograniczyć badania do obszaru Cesarstwa Bizantyńskiego, chociaż zajmuje on w nich miejsce priorytetowe.

Badając reakcje na ekspansję islamu trzeba mieć świadomość ich zróżnicowania $\mathrm{w}$ zależności od wielu czynników, w pierwszym rzędzie od pochodzenia i wyznania polemisty. Pod panowaniem muzułmanów znaleźli się ludzie o bardzo różnych doświadczeniach życiowych, ale też różnych wyznań. Chalcedończycy, nestorianie, monofizyci czy żydzi nieco inaczej postrzegali swych nowych panów i ich wierzenia.

Dla wielu Bizantyńczyków sukcesy islamu były szokujące. Uczucia takie wyrażał, w liście do Piotra, Maksym Wyznawca (ok. 580-662). Nie wymienił islamu z nazwy, ale pisał o cierpieniach, spowodowanych najazdem barbarzyńskiego ludu pustyni, ludu, który traktuje atakowane terytoria jak

${ }^{28}$ Рог. М.В. Кривов, Некоторые вопросы арабского завоевания Сирии и Палестины, „Византийский Временник” 46(71) (1986) 88-99.

${ }^{29}$ Por. S.H. Griffith, Disputes with Muslim in Syriac Christian Texts: From Patriarch John (d. 648) to Bar Hebraeus (d. 1286), w: Religionsgespräche im Mittelalter, hrsg. von B. Lewis F. Niewoehner, Wolfenbütteler Mittelalter-Studien 4, Wiesbaden 1992, 251-273; tenże, Disputing with Islam in Syriac: the Case of the Monk Bēt Hālê and a Muslim Emir, „Hugoye. Journal of Syriac Studies" 3 (2000) nr 1, 1-19.

${ }^{30}$ Por. K. Kościelniak, Grecy i Arabowie. Historia Kościoła melkickiego (katolickiego) na ziemiach zdobytych przez muzułmanów (634-1516), Kraków 2004; zob. też tenże, Złe duchy w Biblii i Koranie, Kraków 1999; tenże, Dżihad. Święta wojna w islamie, Kraków 2006.

${ }^{31}$ Por. D. Madeyska, Historia świata arabskiego. Okres klasyczny od starożytności do roku 750 , Warszawa 1999.

32 Por. M. Sadowski, Chrześcijańska arabskojęzyczna literatura apologetyczna Bliskiego i Środkowego Wschodu w Okresie Abbasydów (750-1050), STHŚO 32 (2012) 87-106.

${ }^{33}$ Por. M. Grodzki, ,Muslims" and ,, islam” in Middle Eastern Literature of the Seventh and Eight Century AD, „Studia Orientalia” 112 (2012) 1-16.

${ }^{34}$ Por. J.W. Żelazny, Patrystyczne świadectwa prób dialogu między chrześcijanami a islamem, w: Wczesne chrześcijaństwo a religie, red. I.S. Ledwoń - M. Szram, Lublin 2012, 303-315. 
swoje i którego członkowie zachowują się jak dzikie bestie ${ }^{35}$. Ważną rolę odgrywał czas. Początkowo sądzono, że najeźdźcy szybko zostaną przepędzeni. Zwracano uwagę na ich okrucieństwo i żądzę łupów. Inwazję arabską postrzegano w kontekście biblijnym, jako karę za grzechy i w kategoriach apokaliptycznych, jako dzieło diabelskie ${ }^{36}$.

Starano się wytłumaczyć ludziom, czemu Arabowie zawdzięczają sukcesy, zarówno militarne jak i religijne. Wyjaśnienia odwoływały się zazwyczaj do przyczyn eschatologicznych: najazd to wypełnienie proroctw starotestamentowych i skutek grzechów popełnianych przez chrześcijan ${ }^{37}$. Już patriarcha Sofroniusz (ok. 560 - 11 III 638; patriarcha od 634) twierdził, że była to kara za ich występki, dawał jednak nadzieję, że jeśli się poprawią - przyjdzie wybawienie $^{38}$. Podobnie myślał Gruzin Teodor, świadek zdobycia Jerozolimy, które jego zdaniem zdarzyło się „za przyzwoleniem Bożym”39. Jan z Nikiu, egipski monofizyta, za winnych uważał zwolenników Soboru Chalcedońskie$\mathrm{go}^{40}$, ale miał też nadzieję na szybkie wypędzenie najeźdźców. Poszukiwano także innych winnych - Żydów i heretyków. Tych pierwszych szczególnie silnie oskarżał Maksym Wyznawca ${ }^{41}$. Anastazy Synaita odpowiedzialnością obarczał cesarza Konstansa II (7 XI 630 - 15 IX 668; cesarz od 641), który doprowadził do wygnania i śmierci papieża Marcina I (ok. 600 - 16 IX 655; papież od 649) ${ }^{42}$. Podobnie przyczyny sukcesów arabskich postrzegał autor Żywota Teodora z Edessy, który oprócz popierania monofizytów i skazania pa-

${ }^{35}$ Por. Maximus Confessor, Epistula 14, PG 91, 540A; zob. Constantelos, The Moslem Conquest, s. 332 .

${ }^{36}$ Nazywano ich barbarzyńskim ludem pustyni, groźnymi, okrutnymi bestiami. Vide teksty Sofroniusza (list synodalny, mowa): niepełne wydanie listu synodalnego: Sophronius Hierosolymitanus, Epistula synodica ad Sergium patriarcham Constantinopolitanum, PG 87/3, 3148A-3200C; tenże, Homilia in Christi natalitia, ed. H. Usener: Weihnatchspredigt des Sophronius, hrsg. von H. Usener, „Rheinischen Museum” N.F. 41 (1886) 501-516. Podstawową biografią Sofroniusza jest: C. von Schönborn, Sophrone de Jérusalem, Vie monastique et confession dogmatique, Paris 1972; por. też Flori, L'Islam et la fin des temps, s. 114.

${ }^{37}$ Walter E. Kaegi (Initial Byzantine Reactions, s. 117) zwraca uwagę, że podobnie poganie postrzegali upadek cesarstwa na Zachodzie.

${ }^{38}$ Por. Sophronius Hierosolymitanus, Homilia in Christi natalitia, ed. Usener, s. 506-507; zob. Flori, L'Islam et la fin des temps, s. 116-117; R.G. Hoyland, Seeing Islam as Others saw it. A Surway and evaluatuin of Christian, Jewish and Zoroastrian Writings on Early Islam, Princeton 1997, 67-73.

${ }^{39}$ Jego świadectwo publikuje Bernard Flusin (L'Esplanade du Temple à l'arrivée des Arabes, d'après deux récits byzantins, w: Bayt al-Maqdis: 'Abd al-Malik's Jerusalem, part 1, ed. J. Raby - J. Johns, Oxford Studies in Islamic Art 9, Oxford 1992, 25-26); por. Flori, L'Islam et la fin des temps, s. 122 i nota 2.

${ }^{40}$ Por. Joannes Niciensis, Chronica 122; zob. Flori, L'Islam et la fin des temps, s. 117-118.

${ }^{41}$ Por. Flori, L'Islam et la fin des temps, s. 121.

${ }^{42}$ Por. Anastasius Sinaita, Sermo III, PG 89, 1156C; zob. Hoyland, Seeing Islam, s. 92-102; Constantelos, The Moslem Conquest, s. 332-333. Anastazy zignorował fakt, że część klęsk, o których wspomina, miała miejsce za Herakliusza. Równocześnie dostrzegał związek między przywró- 
pieża wymienił także inne grzechy Konstansa: zabójstwo brata i okaleczenie Maksyma Wyznawcy ${ }^{43}$. Autor spisanego w VII w. Proroctwa Pseudo-Metodego widział w ekspansji Arabów wypełnienie proroctw Jeremiasza i Daniela, a przyczynę ich sukcesów w grzechach Rzymian i Bizantyńczyków, szczególnie w ich rozwiązłości ${ }^{44}$. Podkreślał, że Bóg wcale nie miłuje Arabów, lecz ich rękoma karze chrześcijan ${ }^{45}$. Do proroctw Daniela (Dn 7, 3-24) nawiązywał też Sebeos $^{46}$. Piszący na początku X w. Aretas podkreślał, że Arabowie popełnili szereg niesprawiedliwości zabijając ludzi ${ }^{47}$, zatem Bóg nie może ich miłować. Wyrażał nadzieję, że wkrótce ich czas się skończy i wypominał im właśnie poniesione klęski ${ }^{48}$.

W zamęcie wojennym nie było mowy o poważniejszej wymianie myśli. Ponadto w czasie pierwszych najazdów ich ofiary w większości nie były świadome, jaką religię wyznają atakujący ich Arabowie. Jeśli nawet opinia Jeana Flori, że „la religion nouvelle est totalment ignorée" ${ }^{49}$, jest nieco przerysowana, bez wattpienia o islamie niewiele wiedziano na terenach zaatakowanych, a jeszcze mniej na dworze cesarskim w Konstantynopolu czy perskim w Ktezyfonie. Trudno byłoby oczekiwać czegoś innego - wszak w początkowym okresie ekspansji Arabów Koran nie był jeszcze spisany, a na Bliskim Wschodzie krążyła mnogość opowieści o Mahomecie (ok. 570 - 8 VI 632) ${ }^{50}$. Niewiele zapewne wnosiły pierwsze bezpośrednie kontakty. Muzułmanie, z którymi spotykali się mieszkańcy Syrii, Egiptu czy Mezopotamii, to świeżo nawróceni na islam wojownicy, którzy zapewne sami nie do końca rozumieli przesłanie Mahometa ${ }^{51}$.

W późniejszym okresie zakres wiedzy był zróżnicowany w zależności od wykształcenia, statusu społecznego, miejsca zamieszkania, wreszcie znajomości języka arabskiego. Inną wiedzą na temat nowej religii dysponowali przedstawiciele elit stolicy, inną Armeńczycy czy mieszkańcy prowincji podbitych przez Arabów. Jan z Damaszku (ok. 675 - 4 XII 749), mieszkaniec Syrii pod

ceniem pokoju religijnego przez Konstantyna IV, a wybuchem walk między muzułmanami (Anastasius Sinaita, Sermo III, PG 89, 1156C-1157B).

${ }^{43}$ Por. Житие и жизнь иже во святых отия нашего Феодора, архиепископа Едесского, ed. В.Г. Васильевский, „Православный Палестинскій Сборникъ” 4 (1886) nr 2, 264-265.

${ }^{44}$ Por. Pseudo-Methodius, Apocalypsis XI 6-7, thum. Tronina, s. 228.

${ }^{45}$ Por. tamże XI 5, thum. Tronina, s. 228. Zob. Kaegi, Initial Byzantine Reactions, s. 118.

${ }^{46}$ Por. Sebeos, Historia de Heraclio 32 i 34, thum. Macler, s. 104-105 i 129-130. Zob. Kaegi, Initial Byzantine Reactions, s. 120-121.

${ }^{47}$ Por. Arethas Caesariensis, Epistula ad ameram Damascenum, ed. Karlyn-Hayter, s. 300.

${ }^{48}$ Wspomniał m.in. sukces Andronika i rozbicie floty arabskiej przez Himeriosa, por. tamże.

${ }^{49}$ Por. Flori, L'Islam et la fin des temps, s. 114 i 122. Jednak cytowany przez tego autora Żyd z Kartaginy (tamże, s. 116) wiedział już o obietnicy raju dla poległych wojowników.

${ }^{50}$ Por. tamże, s. 114-122.

${ }^{51}$ Por. Kaegi, Initial Byzantine Reactions, s. 114. Podobnie sądzi John Tolan (Réactions chrétiennes aux conquêtes musulmanes. Étude comparée des auteurs chrétiens de Syrie et Espagne, „Cahiers de Civilisation Médiévale” 44 (2001) 350-352). 
panowaniem muzułmańskim i urzędnik kalifa ${ }^{52}$, był znacznie lepszej zorientowany w wierzeniach i obyczajach muzułmanów niż przeciętny, nawet wykształcony, mieszkaniec Konstantynopola.

Nie zmienia to faktu, że debata chrześcijan z muzułmanami zapoczątkowana została już za życia Mahometa ${ }^{53}$, gdy obie strony niewiele o sobie wiedziały. Późniejsza tradycja każe kalifom podejmować wysiłki na rzecz zaprezentowania islamu innym ludom. Hadisy przypisują samemu Mahometowi zainicjowanie zwyczaju wysyłania do władców sąsiednich krajów pism wychwalających tę religię i zachęcających do jej przyjęcia ${ }^{54}$. Adresatem jednego z takich pism miał być cesarz Herakliusz (ok. 575 - 11 II 641; cesarz od $5 \times 610)^{55}$. O ile istnieją poważne wątpliwości czy taki list naprawdę został wysłany, to inaczej sprawy mają się w przypadku korespondencji cesarza Leona III z Umarem II ${ }^{56}$. Trudno jednak oczekiwać, by korespondencja dyplomatyczna znacząco poszerzyła wiedzę Bizantyńczyków na temat nowej religii.

To, jak sprawy się miały na samym początku, znakomicie ilustrują pisma Sofroniusza, patriarchy Jerozolimy. Pomimo, iż osobiście spotkał muzułmanów (by wspomnieć słynną rozmowę z Umarem ibn al-Hattābem (ok. 585 3 XI 644; kalif od 23 VIII 634 ${ }^{57}$ ), w swych tekstach nie wspomniał ani słowem $\mathrm{o}$ islamie, ani nie wymienił imienia Mahometa ${ }^{58}$. W Arabach widział po prostu brutalnych najeźdźców. Nazwał ich bezbożnymi Saracenami ${ }^{59}$, co można byłoby odnieść do pogaństwa.

${ }^{52}$ Urząd odziedziczył po ojcu. Żywoty Jana różnią się w opisie w zależności od tego, czy był doradcą kalifa (Żywot arabski), czy też dopiero po długich namowach zgodził się objąć ten urząd (Żywot grecki), por. A. Zhyrkova, Wstęp, w: Jan Damasceński, Dialektyka albo rozdziały filozoficzne. O herezjach, tłum. A. Zhyrkova, ŹMT 59, Kraków 2011, 7-8. W późniejszym okresie życia Jan wstąpił do klasztoru.

${ }^{53}$ Por. S.T. Keating, Defending the „People of the Truth” in the Early Islamic Period. The Christian Apologies of Abu Ra 'itah, Leiden - Boston 2006, 3.

${ }^{54}$ Por. Abel, La lettre polémique, s. 349-350.

${ }^{55}$ Opowieść o korespondencji Mahometa z cesarzem jest zawarta w hadis, znajdującym się w kolekcji Bukhariego (Translation of Sahih Bukhari - Islamic-English Book, transl. by M. Muhsin Khan, vol. 1, Book 1: Revelation, nr 6 - dostępny w sieci https://archive.org/details/TranslationOfSahihAlBukhari-IslamicEnglishBook.pdf_509 [dostęp: 30 X 2014]). Omówienie Czytelnik znajdzie w: L. Pouzet, Le hadith d'Héraclius: une caution byzantine à la prophétie deMuhammad, w: La Syrie de Byzance, s. 59-65.

${ }^{56}$ Por. Leo VI Imperator, Epistula ad Omarum Saracenorum regem, PG 107, 315A - 324B. Zob. Abel, La lettre polémique, s. 348-349. Uczony (tamże, s. 348, nota 1) sądzi, że Leon, autor pisma, to Leon Synkellos, współczesny Niketasowi. Adresatem listu był faktycznie Ibrāhim al-Nağīrami, por. A.A. Vasiliev, Byzance et les Arabes, t. 2: La dynastie macédonienne, cz. 2: Extraits des sources arabes, trad. par M. Canard, Corpus Bruxellense Historiae Byzantinae 2/2, Bruxelles 1930, 203nn.

${ }^{57}$ Umar to przyszły kalif, drugi spośród kalifów prawowiernych (sprawiedliwych). Na temat jego spotkania z Sofroniuszem, por. Kennedy, Wielkie arabskie podboje, s. 85-87.

${ }^{58}$ Podkreślał to już Walter E. Kaegi (Initial Byzantine Reactions, s. 114); por. też Tolan, Réactions chrétiennes, s. 351.

${ }^{59}$ Por. Sophronius Hierosolymitanus, Homilia in Christi natalitia, ed. Usener, s. 514. 
Braku szerszej wiedzy na temat nowej religii Arabów dowodzi rozmowa, do której dojść miało 9 maja 639 r. między jakobickim patriarchą Antiochii Janem II z Amrem ibn Al-Asem. Ten wczesny dialog ${ }^{60}$ wspomina zaledwie podstawowe kwestie, które będą rozwijane w późniejszych tekstach. Co interesujące, przy rozmowie obecni byli chrześcijanie różnych obrządków, także Arabowiechrześcijanie ${ }^{61}$. Patriarcha, wspomagany przez innych dostojników Kościoła ${ }^{62}$, wydawał się nie wiedzieć, że według Koranu Chrystus jest Słowem Bożym ${ }^{63}$. Jan w żadnym momencie dysputy nie cytował wersetów Koranu, podobnie w argumentach podnoszonych przez Amra nieobecne były cytaty biblijne. Gdy Amr odrzucił Księgę Proroków (chociaż jest wspomniana w Koranie), patriarcha ograniczył się do cytowania Tory ${ }^{64}$. Z kolei Amr pytał, czy chrześcijanie mają jedną Ewangelię, a skoro tak, to dlaczego różnią się wierze między sobą ${ }^{65}$. Interesowało go prawo chrześcijańskie; próbował też zanegować boskość Chrystusa $^{66}$. Nie ufając biskupowi, chciał, by prawdziwość cytatów biblijnych potwierdził nieznany z imienia Żyd ${ }^{67}$. Jednak brak wiedzy nie oznaczał braku zainteresowania. Według Michała Syryjczyka (1126 - 7 XI 1199; patriarcha jakobicki (syryjski) Antiochii od 18 X 1166) Amr wyrażał chęć poznania pism chrześcijańskich. Na jego żądanie patriarcha polecił przetłumaczenie ich na język arabski (,,saraceński”), co mieli wykonać schrystianizowani Arabowie ${ }^{68}$.

Pierwszym tekstem, w którym pojawiły się informacje o nowym proroku wśród Arabów, jest dialog Doctrina Jacobi nuper baptizati ${ }^{69}$. Jeden z uczestników dysputy, Justus, powoływał się na list od swego brata Abrahama, w którym znalazły się informacje o pojawieniu się fałszywego proroka, który przybył wraz z Saracenami ${ }^{70}$. Abraham osobiście badał, co ów prorok głosi, wypytując tych, którzy słuchali jego słów.

${ }^{60}$ Tekst wydał, przełożył i opatrzył komentarzem François Nau: Un colloque, s. 225-279 (tekst oryg. s. 248-256; przekład s. 257-267). Dysponujemy także nowym przekładem: The Early Christian-Muslim Dialog. A Collection of Documents from the First Three Islamic Centuries (632900 A.D.), ed. N.A. Newman, Hatfield 1993, 7-46 (przekład tekstu s. 24-28). Tekst został spisany post factum i przesłany innym biskupom. Por. też Michael Syrus, Chronica XI 8, éd. et trad. J.-B. Chabot, t. 2, Paris 1901, 431-432.

${ }^{61}$ Por. Colloquium Joannis patriarchae cum amero Agarenorum 7-9, éd. F. Nau, s. 261-263.

${ }^{62}$ Por. tamże 10.

${ }^{63}$ Por. The Early Christian-Muslim Dialog, s. 8.

${ }^{64}$ Por. Colloquium Joannis patriarchae cum amero Agarenorum 6, éd. F. Nau, s. 260-261.

${ }^{65}$ Por. tamże $1-2$.

${ }^{66}$ Por. tamże 5-7.

${ }^{67}$ Por. tamże 6.

${ }^{68}$ Por. Michel Syrus, Chronica XI 8, éd. et trad. Chabot, t. 2, s. 431-432. Islamski wódz domagał się takiego tekstu Ewangelii, który byłby zgodny z Koranem.

${ }^{69}$ Rozmowa między nawróconym na chrześcijaństwo Jakubem a grupą Żydów miała mieć miejsce 13 lipca $634 \mathrm{r}$.

${ }^{70}$ Por. Doctrina Jacobi nuper baptizati V 16, ed. Deroche, s. 209. Zob. Kaegi, Initial Byzantine Reactions, s. 115-116. 
Dopiero w miarę upływu czasu wiedzę Bizantyńczyków zaczęły poszerzać informacje od chrześcijan pozostających pod panowaniem arabskim. $\mathrm{Ci}$ ostatni byli w stanie czytać tak Biblię jak i Koran, i mogli tłumaczyć Pismo Święte na arabski a Koran na grekę czy syryjski. Muzułmanie, z wyjątkiem konwertytów, znali tylko arabski, dlatego znajomość Biblii wśród uczonych arabskich aż do X w. była stosunkowo słaba, podczas gdy wiedza chrześcijan o islamie szybko się poszerzała. Mimo to trzeba pamiętać, że jeszcze Anastazy Synaita nie nazwał tej religii po imieniu ${ }^{71}$.

Poznawszy rywala można było spróbować podjąć z nim walkę na słowa i argumenty. Były i inne powody, dla których od początku VIII w. przedstawiciele elity chrześcijańskiej zaczęli aktywniej mierzyć się z wyzwaniem muzułmańskim. Przede wszystkim nie można już było mieć nadziei na szybką zmianę sytuacji i zrzucenie władzy kalifów. W pewnym momencie autorzy chrześcijańscy musieli zacząć godzić się z myślą, że usunięcie najeźdźców z zajętych terytoriów nie nastąpi tak szybko, jak się wcześniej spodziewano. Widać to już u Sebeosa i u Anastazego ${ }^{72}$. Dionizjusz z Tell Mahré (ok. 773 - 22 VIII 845; patriarcha jakobicki (syryjski) Antiochii od 818) już nie wierzył w szybkie wypędzenie muzułmanów, chociaż miał nadzieję, że następne pokolenia go doczekają ${ }^{73}$. Także Ghewond (VIII w.) miał nadzieję, że Bóg nie opuści swoich, a w wojnie domowej wśród Arabów widział spełnienie przepowiedni proroka Dawida ${ }^{74}$. Ponieważ jednak nie ziściły się nadzieje na szybkie wypędzenie najeźdźców, trzeba było przyjąć do wiadomości, że zadaniem wyznawców chrześcijaństwa jest przetrwanie w obcym, często wrogim środowisku i zachowanie wiary. Zadaniem elit chrześcijańskich stało się podtrzymanie ducha współwyznawców.

Było to tym ważniejsze, że równocześnie nowa religia okazała się atrakcyjna dla mieszkańców zajętych terytoriów ${ }^{75}$. Już Ghewond zaświadczał, że trwałość władzy arabskiej skłania niektórych do przechodzenia na islam ${ }^{76}$. Był to skutek zarówno działań odgórnych, inicjowanych przez kalifów, jak i indy-

${ }^{71}$ Nie wymienił też Mahometa, ani Koranu (Tolan, Réactions chrétiennes, s. 354-355).

${ }^{72}$ Por. Kaegi, Initial Byzantine Reactions, s. 121.

${ }^{73}$ Por. Pseudo-Dionysius Telmahrensis, Chronica, publ. et trad. par J.-B. Chabot: Chronique de Denys de Tell-Mahré, $4^{\mathrm{e}}$ partie, Bibliothèque de l'École des Hautes Études. Sciences Historiques et Philologiques 112, Paris 1895, 1, lub ed. W. Witakowski: The Syriac Chronicle of Pseudo Dionisius of Tel Mahre, Studia Semitica Upsaliensia 9, Uppsala 1987. Zob. Flori, L'Islam et la fin des temps s. 118.

${ }^{74}$ Por. Ghewond Vardapetus, Historia 5, 19 i 20, transl. by R. Bedrosian, New Jersey $2006=$ www.tertullian.org/fathers/ghewond_01_history.htm [dostęp: 30 X 2014]. Por. Flori, L'Islam et la fin des temps, s. 119-120.

${ }^{75} \mathrm{~W}$ Apokalipsie Pseudo-Metodego (XII 3-6, thum. Tronina, s. 231) odnajdujemy proroctwo, że tak się stanie. W rzeczywistości był to opis stanu faktycznego. Co ważne, autor podkreślał, że ci, którzy wyrzekają się wiary, czynią to „bez przymusu, bez bicia i katuszy” (tamże XII 3, thum. Tronina, s. 231), „dobrowolnie” (tamże XII 6, thum. Tronina, s. 231).

${ }^{76}$ Por. Ghewond Vardapetus, Historia 43 (por. nota 75). Zob. Flori, L'Islam et la fin des temps, s. $119-120$. 
widualnych akcji misyjnych, podejmowanych przez gorliwych muzułmanów. Niezależnie od zakazu nawracania siłą, zawartego w Koranie ${ }^{77}$ i uznania „ludów księgi" za objęte ochroną pod warunkiem, że zapłacą podatek, przeświadczenie o wyższości islamu nad innymi religiami skłaniało kalifów do popierania jego wyznawców i utrudniania życia tym, którzy czcili innych bogów ${ }^{78}$. Polityka taka została zapoczątkowana już za Umajjadów, czego wyrazem była tzw. Konstytucja Umara ${ }^{79}$. Symboliczny wymiar miała budowa meczetu Kopuła na Skale w Jerozolimie, świętym miejscu chrześcijaństwa i judaizmu ${ }^{80}$.

Od połowy VIII w. obserwujemy nasilenie działań mających na celu islamizację terytoriów opanowanych przez Arabów. Anastazy zaświadcza, że podejmowali oni działania wrogie wobec krzyża, ikon i innych form kultu chrześcijańskiego ${ }^{81}$. W okresie abbasydzkim szybko zaczęła rosnąć liczba konwertytów na islam ${ }^{82}$. To z kolei wymagało wythumaczenia, dlaczego tak wielu słucha Mahometa. Pierwotna teza, że to Arabowie, ich ignorancja, głupota, emocjonalność zadecydowały o jego sukcesie, wkrótce przestała wystarczać83.

Kościół musiał odczuć poważne zagrożenie i uświadomić sobie konieczność przeciwdziałania ${ }^{84}$. Literatura polemiczna skierowana była zatem przede

${ }^{77}$ Por. Al-Qur'ān sura II 256, thum. z j. arabskiego J. Bielawski, Warszawa 1986: „Nie ma przymusu w religii”.

${ }^{78}$ Służyło temu np. podnoszenie podatków, usuwanie z przestrzeni publicznej, zmiana systemu monetarnego, por. Keating, Defending the „People of the Truth”, s. 15.

${ }^{79} \mathrm{Na}$ ten temat istnieje ogromna literatura. Najważniejszą monografią jest: A.S. Tritton, $\mathrm{Ca}$ liphs and their Non-Muslim Subjects. A Critical Study of the Covenant of Umar, Delhi 2008. Por. też A. Noth, Problems of Differentiotion between Muslim and Non-Muslim: Re-reading the „Ordinances od Umar", w: Muslims and Others in Early Islamic Society, ed. R. Hoyland, Aldershot 2004, 103-124.

${ }^{80}$ Por. Tolan, Réactions chrétiennes, s. 355; G. J. Reinink, Early Christian Reactions to the Building of the Dome of the Rock in Jerusalem, w: tenże, Syriac Christianity under Late Sasanian and Early Islamic Rule, Collected Studies Series 831, Aldershot 2005, 227-241 (= „Христиансий Восток” 2(8) (2001) 227-241); O. Grabar, The Umayyad Dome of the Rock in Jerusalem, „Ars Orientalis" 3 (1959) 33-62.

${ }^{81}$ Por. Anastasius Sinaita, Diègémata stèriktika C 5, cyt. za: B. Flussin, Démons et Sarrasins. L'auteur et le propos des „Diègémata stèriktika” d'Anastase le Sinaïte, „Travaux et Mémoires” 11 (1991) 387, n. 13 (w tym przypadku to pewien Żyd nie chciał pozwolić na świętowanie przez chrześcijan dnia Matki Bożej). Zob. Flussin, Démons et Sarrasins, s. 406-407. Podobne świadectwa są u Michała Syryjczyka (Chronica XI 8, ed. Chabot t. 2, s. 431).

${ }^{82}$ Por. Keating, Defending the „People of the Truth”, s. 12. Nie wiemy jak w liczbach przedstawiało się to zjawisko, ale o ile ok. 675 r. w Persji tylko 1/3 ludności stanowili muzułmanie, to już w połowie VIII w. ich liczba sięgnęła $40 \%$ populacji (por. tamże).

${ }^{83}$ Por. A.-Th. Khoury, Polémique byzantine contre l'Islam (VIII-XIII s.), Leiden 1972, 137-140. Np. Aretas (Epistula ad ameram Damascenum, ed. Karlyn-Hayter, s. 296) określał muzułmanów jako ulegających emocjom, nie potrafiących kierować się rozumem, myśleć logicznie.

${ }^{84} \mathrm{~A}$. Argyriou (Perception de l'Islam et traductions du Coran dans le monde byzantine grec, „Byzantion” 75 (2005) 25) pisze o zagrożeniu samej egzystencji Kościoła. John Tolan (Réactions chrétiennes, s. 358) sądzi, że skala nawróceń zmusiła teologów chrześcijańskich do zdefiniowania miejsca islamu w dziejach. 
wszystkim do chrześcijan, których miała uzbroić w argumenty w dyskusjach z wyznawcami islamu i zachęcić do pozostania przy wierze przodków. Widać to szczególnie wyraźnie w dziełach Teodora Abu Kurry (ok. 740 - ok. 820), który zamieścił na początku listę pytań, kierowanych przez muzułmanina do jego chrześcijańskiego interlokutora ${ }^{85}$. Podobnie postapił Bartłomiej z Edessy (XII/XIII w.), przytaczając najpierw argumenty przeciwnika ${ }^{86}$.

Z powyższych powodów od początku VIII w. do pierwszych tekstów polemicznych, takich jak wspomniana powyżej relacja z rozmowy jakobickiego patriarchy Antiochii Jana II z Amrem ibn Al-Asem, szybko zaczęły dołączać kolejne. Należy wśród nich wymienić odpowiedź, jakiej cesarz Leon III udzielił kalifowi Umarowi II (719) ${ }^{87}$, anonimową apologię, datowaną przez Samira Khalila Samira na rok 738 lub $771^{88}$, świadectwo Jana z Damaszku ${ }^{89}$, polemikę patriarchy Tymoteusza I (ok. 730 - 823; katholikos nestoriański od 780) z kalifem Al-Mahdim (ok. 745 - 785; kalif od 775) w roku 78190, dialog religijny z Jerozolimy - relacja ze spotkania jakobickiego mnicha z emirem tego miasta

\footnotetext{
${ }^{85}$ Por. Theodorus Abucara, Opuscula ascetica VIII-IX, PG 97, 1528C-1529D. Por. nota 102.

${ }^{86}$ Por. Bartholomaeus Edessenus, Elenchus et confutatio Agareni, PG 104, 1384A - 1385A.

${ }^{87}$ Tekst zachował się u Ghewonda, por. The Early Christian-Muslim Dialog, s. 47-132 (przekład tekstu wraz z fragmentem Ghewonda: s. 57-100). W opinii Roberta Bedrosjana (por. nota 75) jest on późniejszą interpolacją, zatem nie został przez niego przetłumaczony. Na jego temat por. A. Jeffrey, Gevond's Text of the Correspondence between 'Umar II and Leo III, HTR 37 (1944) 269332 (tu też przekład angielski).

${ }^{88}$ Por. K.S. Samir, Une apologie arabe du christianisme d'époque umayyade?, ParOr 16 (19901991) 91, gdzie badacz skłania się jednak ku wcześniejszej z wyżej wspomnianych dat. Na temat tej apologii por. też M.N. Swanson, Beyond Prooftexting: Approaches to the Qur'an in Some Early Arabic Christian Apologies, „The Muslim World” 88 (1998) nr 3-4, 297-319. Manuskrypt wspomnianej apologii znajduje się w Bibliotece Kongresu (sygnatura: Sinaï ar. 154). Tekst wraz z przekładem na język angielski został wydany pod koniec XIX wieku: M. Dunlop Gibson, Studia Sinaitica VII, London 1889, 2-36 (przekład) i 74-107 (tekst arabski). Jednak Samir K. Samir (Une apologie arabe, s. 85-89) wykazał, że w w/w edycji znajdują się poważne błędy, zarówno w odczytaniu tekstu arabskiego, jak i w przekładzie.

${ }^{89}$ Mamy kilka edycji dzieł Jana Damasceńskiego. De haeresibus opublikował J.P. Migne: PG 94, 677A - 780D (na temat islamu: 764A - 773A). Nowe edycje to: John of Damascus on Islam: the „Heresy of the Ishmailites”, ed. D.J. Sahas, Leyde 1972 (wydanie krytyczne i przekład angielski); Jean Damascène, Écrits sur l'Islam, présentation, commentaire et traduction par R. Le Coz, SCh 383, Paris 1992 (s. 210-227: Hérésie 100. L'islam). Dysponujemy także przekładem De haeresibus na język polski (por. nota 53). Jan napisał także dialog Disputatio Saraceni et Christiani, por. Controverse entre un musulman et un chrétien, SCh 383, 228-251; The Early Christian-Muslim Dialog, s. 133-162 (tekst: s. 138-152). Por. też Argyriou, Perception de l'Islam, s. 27.

${ }^{90}$ Por. Timotheus Nestorianus, Apologia Christianorum, ed. A. Mingana: Timothy's Apology for Christianity, w: Woodbrook Studies, vol. 2: Christian Documents in Syriac, Arabic, and Garshūni, ed. and transl. by A. Mingana, Cambridge 1928, 1-162; The Early Christian-Muslim Dialog, s. 163268 (tekst: s. 174-246).
} 
(ok. 800) ${ }^{91}$, apologię Al-Kindiego (1. poł. IX w.) napisaną ok. roku $820^{92}$, homilie Mar Aby II († 2. poł. VIII w.), biskupa z południowego Iraku, katolikosa nestoriańskiego wschodniego Kościoła syryjskiego (741-751) ${ }^{93}$, wreszcie zapis dysputy między mnichem Bet Hale i muzułmańskim możnym (ok. 720) ${ }^{94}$. Do tych tekstów dodać należy dzieła Niketasa z Bizancjum (floruit: 842-867) ${ }^{95}$ i Bartłomieja z Edessy ${ }^{96}$. W późniejszych czasach swoje argumenty przeciw islamowi dołożyli m.in. Eutymiusz Zigaben († ok. 1120), Niketas Choniates (ok. 1155 - ok. 1217), Jan VI Kantakuzen (ok. 1296 - 16 VI 1393; cesarz: 13 V 1347 - 10 XII 1354) i Manuel II Paleolog (27 VI 1350 - 21 VII 1425; cesarz od

${ }^{91}$ Por. The Early Christian-Muslim Dialog, s. 269-354 (tekst zachowany fragmentarycznie: s. 282-340).

${ }^{92}$ Por. Risālat 'Abdallāh ibn-Ismā 'īl al-Hāshimī 'ilā Abd al-Masīh ibn-Ishāq al-Kindī wa-risālat al-Kind̄̄ 'ilā al-Hāshimì (ed. tekstu arabskiego A. Tien, London 1880 [repr. 1885 i 1912]), tekst ten już w 1144 przełożył na język łaciński Piotr z Toledo oraz Piotr z Poitiers (zawiera go tzw. Collectio Toletana) pt. Epistola Saraceni et Rescriptum Christiani, jego edycji dokonał J. Muñoz Sendino (Al-Kindi, Apologia del Cristianismo, „Miscellánea Comillas” 11/12:1949, 375-460), a ostatnio wraz z przekładem hiszpańskim F. González Muñoz (Exposición y refutación del Islam. La version Latina de las epistolas de al-Hāšimī y al-Kindī, Univ. da Coruña, Coruña 2005). Posiadamy też kilka innych przekładów nowożytnych tego dzieła - włoskie: Al-Kindi, Apologia del cristianesimo, traduzione dall'arabo, introduzione e cura di L. Bottini, Patrimonio di Cultura Arabo-Cristiana 4, Milano 1998; angielskie: W. Muir, The Apology of Al Kindy written at the Court of Al-Māmūn, New York 1887, lub The early Christian-Muslim dialogue. A collection of documents from the first three Islamic centuries (632-900 A.D.), trad. N.A. Newman, Hatfield (Pa.) 1993, 355-546 (tekst s. 381402 i 411-516); francuskie: G. Pasteur Tartar, Dialogue islamo-chrétien sous le calife al-Mamun (813-834). Les épitres d'al-Hashimi et d'al-Kindi, Paris 1985. W niniejszym artykule posługuję się włoskim przekładem Laury Bottini.

${ }^{93}$ Por. Reinink, Political Power, s. $155 \mathrm{nn}$.

${ }^{94}$ Por. tamże, s. 157nn; Griffith, Disputes with Muslim, s. 251-273; tenże, Disputing with Islam, s. 1-19.

${ }^{95}$ Nicetas Byzantinus, Confutatio dogmatum Mahomedis [vel] Confutatio falsi libri quem scripsit Mahomedes Arabs, PG 105, 669A-841C. W skład tego traktatu wchodzą też dwa funkcjonujące niekiedy samodzielnie pisma: Expositio demonstrativa Christiani dogmatis (PG 105, 808A - 821C) oraz Confutatio et eversio secundae epistulae ab Agarenis missae ad Michaelem imperatorem (PG 105, 821D - 841C). Nicetas jest również autorem traktatu Refutatio epistulae regis Armeniae [vel] Confutatio et eversio epistulae ab Armeniae principe missae (PG 105, 588A - 665C). Zob. Argyriou, Perception de l'Islam, s. 27.

${ }^{96}$ Por. Bartholomaeus Edessenus, Elenchus et confutatio Agareni, PG 104, 1384A - 1448A; tenże, Contra Muhammed, PG 104, 1448B - 1457D (autorstwo Bartłomieja w przypadku tego utworu jest obecnie kwestionowane)). Istnieje nowa edycja, do której nie udało mi się niestety dotrzeć: Bartholomaios von Edessa, Confutatio Agareni, kommentierte griechisch-deutsche Textausgabe von K.-P. Todt, Corpus Islamo-Christianum. Series Graeca 2, Würzburg 1988. Elenchus et onfutatio Agareni składa się z kilku mniejszych tekstów, zredagowanych w różnym czasie, na bazie pierwotnego tekstu Bartłomieja. Ten ostatni ma formę listu do fikcyjnego Hagarena (por. Argyriou, Perception de l'Islam, s. 30-31). Por. też Ю.В. Максимов, Варфоломей Эдесский об Исламе, w: Византийские сочинения об Исламе, отред. Ю.В. Максимова, Москва 2012, 86-91 (tu też przekład tekstu Bartłomieja na rosyjski: Варфоломей Эдесский, Обличение Агарянина, s. 92-129). 
16 II 1391), jednak ich dzieła nie będą już przedmiotem analizy ${ }^{97}$, wykraczają bowiem poza określone ramy niniejszego artykułu.

$\mathrm{W}$ polemikach z muzułmanami ważną rolę odegrała literatura chrześcijańska pisana po arabsku, co było spowodowane upowszechnianiem się tego języka ${ }^{98}$. W ciągu pierwszego stulecia rządów Abbasydów na arabski przełożono nie tylko Biblię, ale także najważniejsze chrześcijańskie teksty liturgicz$n^{99}$. W takiej sytuacji należało podjąć walkę $\mathrm{z}$ islamem na gruncie jego języka. Tłumaczy to wysyp kolejnych apologii, napisanych po arabsku. Zjawisko to było spowodowane także faktem, że niektórzy spośród władców arabskich przejawiali zainteresowanie kwestiami religijnymi i inicjowali debaty. Tymoteusz, wspomniany już nestoriański katolikos, na prośbę kalifa Al-Mahdiego wyłożył mu naukę chrześcijańską ${ }^{100}$. Pisał po syryjsku, ale lepiej znana jest wersja arabska jego dzieła.

Jego następcy zdecydowali się już dyskutować z muzułmanami w ich własnym języku. Wśród arabskich apologii chrześcijaństwa wymienić należy teksty Teodora Abu Kurry ${ }^{101}$, Abu Ra'ițah al-Takritiego (ok. 775 - ok. 835)

${ }^{97}$ Warto wymienić dzieła dwu pierwszych: Euthymius Zigabenus, Panoplia dogmatica ad Alexium Comnenum XXVIII: Adversus Saracenos, PG 130, 1332D - 1360D; Nicetas Choniata, Thesaurus orthodoxae fidei XX 1-18, PG 140, 105A - 121C. Omówienie ich prac Czytelnik znajdzie w artykule: Argyriou, Perception de l'Islam, s. 40-59.

${ }_{98}$ Por. Sadowski, Chrześcijańska arabskojęzyczna literatura, s. 90-92; Tolan, Réactions chrétiennes, s. 354. Sandra T. Keating (Defending the „People of the Truth, s. 19) użyła trafnego określenia „the new lingua franca” dla określenia postępów arabizacji.

${ }^{99}$ Por. Keating, Defending the „People of the Truth”, s. 20.

${ }^{100}$ Por. nota 91.

${ }^{101}$ Por. Theodorus Abucara, Opuscula ascetica [vel] Contra haereticos, Iudaeos et Saracenos varia opuscula, PG 97, 1461A-1601C; Die arabischen Schriften des Theodor Abu Qûrra, Bishofs von Harrân (ca. 740-820): literarhistorische Untersuchungen und Übersetzung, hrsg. von G. Graf, Forschungen zur Christlichen Literatur- und Dogmengeschichte 10/3-4, Paderborn 1910. Na temat jego postaci i twórczości por. S.H. Griffith, Theodore Abu Qurrah. The Intelectual Profile of an Arab Christian Writer of the First Abbasid Century, Tel Aviv 1992; tenże, Reflections on the Biography of Theodore Abu Qurrah, ParOr 18 (1993) 143-170; J.C. Lamoreaux, Theodore Abu Qurrah and John the Deacon, GRBS 42 (2001) 361-386; tenże, The Biography of Theodore Abu Qurrah Revisited, DOP 56 (2002) 25-40; I. Dick, Un continuateur arabe de saint Jean Damascène, Théodore Abuqurra, évêque melchite de Harran. La personne et son milieu, cz. 1: Les études antérieures sur Abuqurra, POC 12 (1962) 209-223; cz. 2: Analyse des sources, POC 12 (1962) 319-332; cz. 3 : Essai d'une esquisse historique, POC 13 (1963) 114-129; tenże, La discussion d'Abū Qurra avec les ulémas musulmans devant le calife al-Ma'mūn, ParOr 16 (1990-1991) 107-113; A.-Th. Khoury, Les théologiens byzantins et l'Islam, t. 1: Textes et auteurs (VIII'-XIII' siècle), Louvain - Paris 1969, 83-105; Ł. Karczewski, Dialog Teodora Abu Kurra ze światem islamu-zarys problematyki, „Seminare” 33 (2013) 277-292; Meyendorff, Byzantine Views of Islam, s. 120-121; Ю.В. Максимов, Феодор Абу-Курра об Исламе, w: Византийские сочинения об Исламе, s. 23-30; W. Nasry, The Caliph and the Bishop. A $9^{\text {th }}$ Century Muslim-Christian Debate: Al-Ma'mun and Abu Qurrah, Beyrouth 2008; S.L. Husseini, Early Christian Explanations of the Trinity in Arabic in the Context of 
- powstałą między rokiem 810 a $825^{102}$, Al-Kindiego ${ }^{103}$, Ibrahima Al-Tabaraniego (ok. 825), datowany na ok. 825, 'Ammar al-Bașriego (floruit: ok. 825$840)^{104}$, Al-Rahiba (ok. 840) i Butrusa al-Shammas ibn Nastasa al-Bayt Rasiego (IX wiek) $)^{105}$.

Wszystkie wymienione powyżej teksty miały za cel obronę chrześcijaństwa. Ze strony muzułmańskiej głos zabrali dopiero, atakując chrześcijaństwo z błogosławieństwem kalifa Al-Mutawakkila (822-861; kalif od 847), Al-Tabari (839-923) w Księdze religii ${ }^{106}$, Al-Jahiz (ok. 776 - ok. 869) w Odpowiedzi chrześcijanom (ok. 869) $)^{107}$, wreszcie Ibn al-Munağğim $(† 912)^{108}$, w listach adresowanych do Hunayn ibn Ishaqa (809-873) i Qusta ibn Luqua (820/835912). W grupie polemistów antychrześcijańskich wymienić trzeba także Abu Isę al-Warraka (IX w.), którego traktat jest datowany około roku $861^{109}$.

Powyższej dysproporcji trudno się dziwić, biorąc pod uwagę fakt, iż przed islamem kultura arabska była kulturą słowa mówionego, nie zaś pisma. Nie bez znaczenia było też to, że chrześcijanie mieli już za sobą długi ,trening” w postaci dyskusji z poganami i żydami.

Muslim Theology, University of Birmingham Research Archive e-Theses Repository, Birmingham 2011, 77-141; B.A. Nassif, Religious Dialogue in the Eight Century, ParOr 30 (2005) 333-340.

${ }^{102}$ Nieliczne znane fakty z jego biografii odtwarza Sandra T. Keating (Defending the „People of the Truth, s. 32-47), wskazując, że nie był on biskupem Takritu, jak chce tradycja (por. tamże, s. 4047). Uczona publikuje też teksty Abū Rā'iṭaha, z przekładem na język angielski (por. tamże, s. 82-146, 164-216, 222-298, 308-334 i 352-358). Inne wydanie: Die Schriften des Jacobiten Habīb ibn Khidma Abū Rā 'ita, CSCO 130, Louvain 1951. Por. Husseini, Early Christian Explanations, s. 142-197.

${ }^{103}$ Por. nota 92.

${ }^{104}$ Por. Husseini, Early Christian Explanations, s. 198-266; W.Y.F. Mikhail, ‘Ammār al-Bașrī’s Kitāb al-Burhān: A Topical and Theological Analysis of Arabic Christian Theology in the Ninth Century, [University of Birmingham Research Archive e-Theses Repository], Birmingham 2013.

${ }^{105}$ Por. Samir, Une apologie arabe, s. 85; tenże, Prophet Muhammed seen through Arab Christian Eyes, w: Syrian Christians Under Islam: The First Thousand Years, ed. D.R. Thomas, Leiden 2001, 82 .

${ }^{106}$ Por. Ali al-Tabari, Riposte aux chrétiens, trad. J.-M. Gaudeul, Roma 1995; The Early Christian-Muslim Dialog, s. 547-684 (tekst: s. 568-657).

${ }^{107}$ Por. The Early Christian-Muslim Dialog, s. 685- 717 (tekst: s. 699-709).

${ }^{108}$ Jego list wraz z odpowiedziami chrześcijańskich adresatów ukazały się w przekładzie na język polski: Korespondencja między chrześcijaninem a muzułmaninem, tłum. J.A. Szymańczyk, ŹMT 36, Kraków 2005. Na temat argumentów obrońcy chrześcijaństwa, por. I. Zilio-Grandi, La refutazione della profezia di Muhammad e del miracolo coranico di Qusta ib Luga, ParOr 22 (1997) 677-689.

${ }^{109}$ Por. Anti-Christian Polemic in Early Islam: Abū 'İsā al Warrāq's „Against the Trinity”, ed. and transl. by D. Thomas, University of Cambridge Oriental Publications 45, Cambridge1992; Muslim Polemic against Christianity: Abū 'İsā al Warrāq's ,,Against the Incarnation”, ed. and transl. by D. Thomas, University of Cambridge Oriental Publications 59, Cambridge 2002; D. Thomas, Abu 'İ̄a al Warrāq and the History of Religion, „Journal of Semitic Studies” 41 (1996) nr 2, 275290; E. Platti, La doctrine des chrétiens d'après Abū 'İsa al-Warrāq dans son traité sur la Trinité, „Mideo" 20 (1991) 7-30; Muslim Perceptions of Other Religions: A Historical Survey, ed. J. Waardenburg, Oxford 1999. 
Niektóre polemiki bizantyńskie powstawały w odpowiedzi na teksty wychwalające islam. Tak było w przypadku listu Aretasa. Przypomina on podobne pisma, sporządzane w imieniu Michała III (9/10 I 833 - 23/24 IX 867; cesarz od 20 I 842) przez Niketasa ${ }^{110}$, ale nie był oficjalną odpowiedzia, wysłaną za pośrednictwem kancelarii cesarskiej. Jak wspomniano powyżej, Hunayn Ibn Ishaq i Qusta Ibn Luqua odnosili się w swych listach do tez zawartych W piśmie Ibn al-Munaqqima ${ }^{111}$. Również Al-Kindi został sprowokowany do napisania Apologii chrześcijaństwa. Swym dziełem odpowiadał na zarzuty stawiane przez Abd Allaha al-Hashimiego (floruit: ok. 890) ${ }^{112}$.

Pierwsza zachowana apologia chrześcijańska powstała w środowisku melkickim $^{113}$. Jej autor we wprowadzeniu do właściwego tekstu zawarł wiele odniesień do Koranu ${ }^{114}$, dowodząc nienajgorszej orientacji w tekście świętej księgi muzułmanów. Fakt powyższy skłonił Khalila Samira do konstatacji, że autor apologii nie żył w izolowanym getcie chrześcijańskim, lecz uczestniczył w kulturze arabskiej ${ }^{115}$. To zapewne miało wpływ na charakter jego wywodu - nieagresywny, pokojowy wykład doktryny, mający pokazać, że chrześcijaństwo jest religią dobrą dla człowieka ${ }^{116}$. W pierwszej części apologii zebrane zostały argumenty na rzecz prawdziwości dogmatu Trójcy Świętej ${ }^{117}$. Dalej autor prezentował ideę wcielenia wskazując, że Bóg wysłał swe Słowo wcielone, by pokonać szatana, uwolnić ludzkość od grzechu i zagwarantować jej zmartwychwstanie ${ }^{118}$. Tym samym określone zostały podstawowe punkty sporne między obu religiami.

Znacznie szerszy oddźwięk, niż tekst cytowany powyżej, miały pisma Jana z Damaszku. Warto przedstawić obszerniej jego poglądy, ponieważ wpłynął on na postawy wielu innych Bizantyńczyków ${ }^{119}$. Z argumentów zawartych w jego dziele korzystali zarówno dziejopisowie, w pierwszym rzędzie

\footnotetext{
${ }^{110}$ Por. Karlyn-Hayter, Arethas's Letter, s. 281. Zob. Abel, La lettre polémique, s. 347-349.

111 Por. nota 109.

112 Jego list w przekładzie włoskim zamieszcza Laura Bottini (Al-Kindi, Apologia del cristianesimo, s. 39-71).

${ }^{113}$ Por. Samir, Une apologie arabe, s. 92 i 105. Autor podkreśla, że w Damaszku wśród chrześcijan dominowali melkici i że nieprzypadkowo pierwszy tekst chrześcijański spisany po arabsku był tekstem melkickim.

114 Por. tamże, s. 97.

${ }_{115}$ Por. tamże, s. 105.

116 Por. tamże, s. 105. Badacz zwraca też uwagę na inne cechy charakterystyczne analizowanego tekstu: brak argumentacji filozoficznej, homiletyczny styl i oparcie się na Biblii i tekstach patrystycznych (tamże, s. 120-121).

117 Por. tamże, s. 97-98.

118 Por. tamże, s. 100-102.

119 Jego dzieła były tłumaczone na arabski i wykorzystywane także przez teologów muzułmańskich, por. Tolan, Réactions chrétiennes, s. 358.
} 
Teofanes Wyznawca ${ }^{120}$ i Jerzy Mnich (floruit: 842-867) ${ }^{121}$, jak i teolodzy. O ile dziejopisowie tylko ogólnikowo i niejako na marginesie swych relacji odnosili się do kwestii teologicznych, o tyle dla teologów te ostatnie miały znaczenie priorytetowe. To na ich barkach spoczął główny ciężar zmagań ideologicznych $\mathrm{z}$ islamem.

Jan był członkiem chrześcijańskiej elity Damaszku. Ze względu na to, że żył w środowisku muzułmańskim, miał szansę dobrze poznać nową religię. Opis islamu, zawarty w ostatnim rozdziale jego traktatu $O$ herezjach ${ }^{122}$, jest jego autorskim dziełem ${ }^{123}$. Jan znał Koran, jeśli nie $\mathrm{z}$ osobistej lektury, to $\mathrm{z}$ drugiej ręki. Cytował go, chociaż w krótkich fragmentach i niezbyt precy$z^{z y j n i e^{124}}$. Sury nazywał pismami $(\gamma \rho \alpha \varphi \alpha i)^{125}$, jakby były odrębnymi tekstami.

Dla Jana muzułmanie byli barbarzyńcami, najeźdźcami, uzurpatorami, niszczycielami porządku społecznego i religijnego ${ }^{126}$. Jak dla wszystkich chrześcijan, źródłem wiedzy była dlań Biblia. Nazwę Izmaelici Jan wywodził od Izmaela, syna Hagar i Abrahama. Od imienia matki nazywał ich Hagarena-

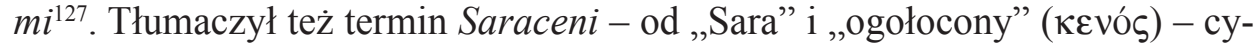
tując słowa Hagar, iż Sara wyrzuciła ją ogołoconą (Rdz 16, 8-9) ${ }^{128}$. Pisał o nich z ironią i sarkazmem. Zarzucał im, iż są bałwochwalcami - czczą Gwiazdę Poranną i Afrodytę Chabar (Wielką). Miał jednak świadomość, że to oskarżenie nie jest do utrzymania w jego epoce, bowiem zaraz dodał, że byli nimi do czasów Herakliusza $^{129}$.

120 Por. nota 4.

${ }^{121}$ Por. Georgius Monachus, Chronicon, ed. C. de Boor, vol. 2, Lipsiae 1904 = PG 110, 41A $1285 \mathrm{D}$ (tu inny podział wewnętrzny dzieła).

${ }^{122} \mathrm{Na}$ temat edycji dzieł Jana por. nota 90.

123 Por. nota 53 i 90.

${ }^{124} \mathrm{Na}$ przykład swą polemikę zakończył luźnym cytatem wersetu 115 z sury V, por. Argyriou, Perception de l'Islam, s. 28-29).

${ }^{125}$ Por. Joannes Damascenus, De haeresibus 6, 2, ed. R. le Coz, SCh 383, 220, tłum. A. Zhyrkova, ŹMT 59, 137; tamże 8, 2, SCh 383, 224, ŹMT 59, 139; tamże 8, 5, SCh 383, 226, ŹMT 59, 139. Wymienił pisma Kobieta (= sura IV): tamże 6, 1-24, SCh 383, 220-222, ŹMT 59, 137-138; Stót zastawiony (= sura V): tamże 8, 1-4, SCh 383, 224-226, ŹMT 59, 139; Byczek (= sura II): tamże 8, 5-6, SCh 383, 226, ŹMT 59, 139. Za pismo koraniczne uznał też tekst Wielbładzica Boża (tamże 7 , 1-43, SCh 383, 222-224, ŹMT 59, 138-139), którego w Koranie nie ma.

${ }^{126}$ Por. Zhyrkova, Wstęp, s. 21.

${ }^{127}$ Por. Joannes Damascenus, De haeresibus 1, 1-7, SCh 383, 210, ŹMT 59, 135.

${ }^{128}$ To ciekawa, chociaż błędna próba etymologii. W rzeczywistości nazwa Saraceni nie ma związku z Biblią. Pojawiła się na długo przed narodzinami chrześcijaństwa. Pierwszym autorem, który nazwał tak mieszkańców Półwyspu Arabskiego był Pliniusz Starszy. Nie jest pewne, jaki był źródłosłów tej nazwy. Szerzej na ten temat por. М.Д. Бухарин, Происхождение этнонима

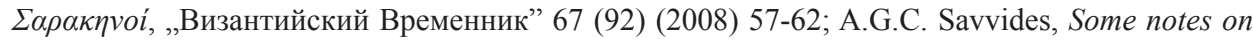
the Term Agarenō̄, Ismaelìtai and Sarakenō in Byzantine Sources, „Byzantion” 67 (1997) 89-96.

${ }^{129}$ Por. Joannes Damascenus, De haeresibus 1, 9-13, SCh 383, 210, ŹMT 59, 135; Bartholomaeus Edessenus, Contra Muhammed, PG 104, 1448B. 
Na początku VIII w. muzułmanie nie byli już poganami, lecz - w opinii Jana - heretykami ${ }^{130}$. Damasceńczyk sugerował, że Mahomet (Mamed) przez przypadek przeczytał Stary i Nowy Testament, a ponadto został pouczony przez jakiegoś mnicha ariańskiego, wskutek czego „naskrobał” jakieś „śmiechu warte rozprawy" i pyszni się, że zostało mu to przekazane przez Boga ${ }^{131}$. $\mathrm{Z}$ tego powodu islam był w ocenie Jana kultem zwodniczym, zwiastunem Antychrysta, herezją $a^{132}$.

Charakteryzując religię Mahometa Jan sięgał do Koranu, przytaczając najważniejsze elementy jego nauczania. Szczególną uwagę zwrócił na monoteizm islamski, cytując werset „Bóg [...] nie jest ani zrodzony, ani rodzący”133, oraz na te elementy nowej religii, które były polemiczne względem chrześcijaństwa. Podkreślał, że dla wyznawców islamu Chrystus to Słowo i Duch Boga, ale nie jego Syn, że ich zdaniem jest on stworzony i jest niewolnikiem Boga, oraz że nie został ukrzyżowany (na krzyżu zawisł jego cień), lecz został wzięty do nieba ${ }^{134}$. Sam Chrystus miał ganić uczniów za to, że uznają go za Syna Bożego ${ }^{135}$. Zdaniem Jana W. Żelaznego to właśnie odrzucenie bóstwa Chrystusa było w opinii Jana z Damaszku główną cechą islamu ${ }^{136}$.

O założycielu nowej religii Jan z Damaszku wyrażał się z lekceważeniem, jako o „pseudoproroku”. Zarzucał mu niemoralność - dał każdemu prawo brania czterech żon i tylu nałożnic, ile zechce, a także swobodnego odprawiania małżonek, bowiem sam chciał posiąść żonę innego ${ }^{137}$. Podkreślał, że nie ma świadków tego, że misja Mahometa pochodziła od Boga (ponoć objawienie otrzymał, gdy spał). Nikt też nie zapowiedział jego przyjścia ${ }^{138}$. Jan polemizował z muzułmańskim zarzutem, iż chrześcijanie dodają Bogu „koleżków”, czyli że są politeistami ${ }^{139}$. Zarzucał im niekonsekwencję, pisząc, że skoro

${ }^{130}$ Por. Joannes Damascenus, De haeresibus 1, 13-16, SCh 383, 210-212, ŹMT 59, 135.

${ }^{131}$ Por. tamże 1, 13-20, SCh 383, 210-212, ŹMT 59, 135. W innym miejscu ocenia opinie wyrażone w surze 2 jako ,śmiechu warte" (tamże 3, 1-3, SCh 383, 214, ŹMT 59, 135; tamże 8, 5-6, SCh 383, 226, ŹMT 59, 139).

${ }^{132}$ Por. tamże 1, 1-3, SCh 383, 210, ŹMT 59, 135.

${ }^{133}$ Tamże; Al-Qur'ān sura CXII 1-4 (w przekładzie J. Bielawskiego, s. 736: „Nie zrodził i nie został zrodzony").

${ }^{134}$ Por. Joannes Damascenus, De haeresibus 2, 1-19, SCh 383, 212, ŹMT 59, 135.

${ }^{135}$ Por. tamże 2, 11-18, SCh 383, 212, ŹMT 59, 135; Georgius Monachus, Chronicon, ed. de Boor, vol. 2, s. 700 (= PG 110, 868A). Zob. Sadowski, Chrześcijańska arabskojęzyczna literatura, s. $98-100$.

${ }^{136}$ Por. Żelazny, Patrystyczne świadectwa prób dialogu, s. 309. Równocześnie jednak Damasceńczyk podkreślał, że według Koranu Bóg na prośbę Chrystusa zesłał jemu i tym, którzy z nim byli „stół zastawiony” (Al-Qur'ān sura V 114-115, tłum. J. Bielawski, s. 149. Wg innych przekładów ,posiłek nieśmiertelny”).

${ }^{137}$ Por. Joannes Damascenus, De haeresibus 6, 1-12, SCh 383, 220, ŹMT 59, 137.

${ }^{138}$ Por. tamże 3, 18-29, SCh 383, 214-216, ŹMT 59, 136. Zob. Żelazny, Patrystyczne świadectwa prób dialogu, s. 309.

${ }^{139}$ Por. Joannes Damascenus, De haeresibus 4, 1-3, SCh 383, 216, ŹMT 59, 136. Nawiązywał 
uznaja, że jest on Słowem Boga, to tym samym uznają go za Boga, bo duch i słowo nie istnieją oddzielnie od tego w kim istnieją ${ }^{140}$. Podobnie odrzucał płynącą z ich strony krytykę kultu krzyża. Twierdził, że sami czczą kamień, będący głową Afrodyty Chabar. Równocześnie jednak utrzymywał, że Arabowie wierza, iż na tym kamieniu Abraham współżył z Hagar lub że jest to kamień, na którym miał zostać ofiarowany Izaak ${ }^{141}$.

Większość informacji Jana na temat zasad islamu jest poprawna. Wiedział, że muzułmanom nie wolno czcić szabatu, przyjmować chrztu, czy pić wina. Moga za to jeść rzeczy zakazane przez Prawo Mojżeszowe (nie wymienił jakie), choć nie wolno spożywać im innych (też nie wymienionych) ${ }^{142}$. Zdarzają się jednak i błędne dane. Nie wiadomo, skąd Damasceńczyk zdobył informację, że Saraceni przechodzą obrzezanie wraz z żonami ${ }^{143}$. Podobnie niejasne jest, skąd zaczerpnął tekst Wielbładzica Boża ${ }^{144}$, którego nie ma go w Koranie, ani w tradycji muzułmańskiej.

Następcy Jana kontynuowali jego dzieło i twórczo rozwijali argumentację antyislamską. Ważne z punktu widzenia niniejszego artykułu teksty polemiczne wyszły spod piór Bartłomieja z Edessy i Niketasa z Bizancjum.

Pierwszy z wymienionych był mnichem syryjskim, ortodoksą żyjącym w środowisku nestoriańskim. Znał syryjski i arabski, a może też perski i grekę. Żył w środowisku, w którym można było świetnie poznać religijną literaturę islamską i nestoriańską ${ }^{145}$. Twierdził, że przeczytał wszystkie pisma muzułmańskie, w szczególności Koran, ale nie dowiódł jego dobrej znajomości w swojej polemice ${ }^{146}$. Cytował raczej teksty popularne, często legendarne. Znał niektóre hadisy ze zbioru Ibn Ishaka ${ }^{147}$ Do Koranu odnosił się sporadycznie. Twierdził, że zawiera on to, co nestoriański mnich Bahira przekazał Mahometowi i to, co dodał doń Utman ${ }^{148}$. Tej drugiej części odmawiał wszelkiej

do obecnego w Koranie (m.in. sura II 116; sura V 73; sura VII 33; sura XIX 35) wezwania, by nie dodawać Bogu towarzyszy i negacji bóstwa Chrystusa. Wskazywał, że sami muzułmanie też oddzielają Boga od Ducha.

${ }^{140}$ Por. tamże 4, 11-15, SCh 383, 218, ŹMT 59, 136-137.

${ }^{141}$ Por. tamże 5, 1-21, SCh 383, 218-220, ŹMT 59, 137. Zob. Żelazny, Patrystyczne świadectwa prób dialogu, s. 309.

${ }^{142}$ Por. Joannes Damascenus, De haeresibus 8, 7-10, SCh 383, 226, ŹMT 59, 139; Georgius Monachus, Chronicon, ed. de Boor, vol. 2, s. 700 (= PG 110, 868A-B).

${ }^{143}$ Por. Joannes Damascenus, De haeresibus 8, 7, SCh 383, 226, ŹMT 59, 139.

${ }^{144}$ Może opowieść o wielbłądzicy, która była matką wielbłądziczki, chociaż nie pokrył jej żaden wielbłąd (por. nota 126) była złośliwą parafrazą tekstu Ewangelii.

${ }^{145}$ Por. Argyriou, Perception de l'Islam, s. 32.

${ }^{146}$ Por. Bartholomaeus Edessenus, Elenchus et confutatio Agareni, PG 104, 1389A i 1392A. Znał

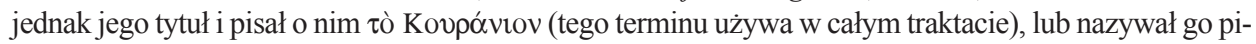

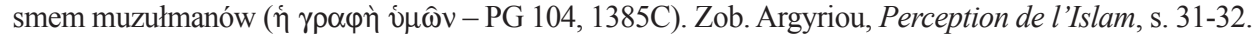

${ }^{147}$ Por. Максимов, Варфоломей Эдесский об Исламе, s. 88.

${ }^{148}$ Por. Bartholomaeus Edessenus, Elenchus et confutatio Agareni, PG 104, 1389D. Co ciekawe, fragmenty pochodzące od mnicha miały być prawdziwe, natomiast dodane przez kalifa to fałsz. 
wartości. Trzeba pamiętać, że nie zamierzał obiektywnie przedstawić islamu, lecz zaprezentować jego wypaczony, karykaturalny obraz ${ }^{149}$.

Niketas z Bizancjum, profesor szkoły wyższej w Konstantynopolu, napisał trzy traktaty antyislamskie. Powstały one na krótko przed spisaniem pierwotnej wersji tekstu Bartłomieja ${ }^{150}$. Dwa pierwsze miały postać listów, napisanych w odpowiedzi na pisma wysłane przez „Agarenów” do cesarza Michała ${ }^{151}$.

Traktat Refutatio Agareni ${ }^{152}$ został napisany po sukcesach militarnych Michała III w latach $855-856^{153}$. Autor dobrze orientował się w zawartości świętej księgi islamu i poprawnie zaprezentował czytelnikowi jej zawartość. Wiedział, że składa się ze $113 \mathrm{ksiag}$, znał tytuły wielu z nich (32) ${ }^{154}$, zacytował też pokaźną liczbę wersetów. Fragmenty, w których streszczał sury Koranu, są napisane kompetentnie, a tezy pisma streszczane poprawnie, bez przekłamań, z oddaniem sensu. Współczesny uczony, Asterios Argyriou, z uznaniem wypowiada się o wysiłku translatorskim Niketasa, twierdząc, że w żadnym momencie nie przeinaczał on tekstu, chociaż zdarzało mu się źle zrozumieć niektóre wersety ${ }^{155}$. Trzeba jednak pamiętać, że podobnie jak jego poprzednicy, Niketas starał się znaleźć w Koranie broń przeciw islamowi. Dobierał tłumaczone fragmenty tak, by wykazać, że Mahomet nie był prawdziwym prorokiem, a islam nie jest prawdziwą religią. Chociaż zatem jego tekst zawiera najlepsze informacje o islamie, daleki jest od obiektywizmu. Niketas udowadniał na przykład, że islam jest religią panteistyczna, kontynuacją politeizmu, wyznawanego przez Arabów przed Mahometem ${ }^{156}$. Podobne zarzuty pobrzmiewają w tekście Jerzego Mnicha, który zinterpretował muzułmańskie zawołanie „Bóg jest wielki” jako „Bóg jest większy niż bogini Afrodyta”157.

Nie wiadomo, czy Niketas dysponował przekładem Koranu, czy korzystał z usług tłumacza. A. Abel sądzi, że sam go tłumaczył, bowiem spędził długi czas w Bagdadzie jako jeniec i znał arabski ${ }^{158}$.

${ }^{149}$ Por. Argyriou, Perception de l'Islam, s. 32.

${ }^{150}$ Por. tamże, s. 32-33.

${ }^{151}$ Michał III panował w latach 842-967. Powstanie listów Niketasa A. Argyriou (Perception de l'Islam, s. 33) datuje na czas między 850 a 855 r.

${ }^{152}$ Edycje tekstu, por. nota 96.

${ }^{153}$ We wstępie znajdujemy pochwałę cesarza (Nicetas Byzantinus, Confutatio dogmatum Mahomedis 1, PG 105, 669A - 672B). Por. Argyriou, Perception de l'Islam, s. 34.

${ }^{154}$ Szczegółowa analiza w: Argyriou, Perception de l'Islam, s. 35-40.

${ }^{155}$ Por. tamże, s. 37-38. Uczony jako przykłady przytacza omówienie fragmentów sury VII 10 30 (upadek Iblisa) i XVIII 18-22 (opowieść o siedmiu śpiących).

${ }^{156}$ Por. Nicetas Byzantinus, Confutatio dogmatum Mahomedis XVIII 83, PG 105, 776D - 777C. Zob. Argyriou, Perception de l'Islam, s. 39.

${ }^{157}$ Georgius Monachus, Chronicon, ed. de Boor, vol. 2, s. 706 (= PG 110, 874A), thum. własne. Por. Bartholomaeus Edessenus, Contra Muhammed, PG 104, 1456B.

${ }^{158}$ Por. Abel, La lettre polémique, s. 347, nota 2. Uczony nie wyklucza, że Niketas celowo przeinaczył tekst arabski przekładając „walczyć” (qātala) jako „zabijać” (qatala) - co sugerowało, że muzułmanie mają prawo zabijać tych, którzy dodają Bogu towarzyszy. Szerzej na temat znajomości 
W kolejnych 17 rozdziałach dzieła Niketasa znajdujemy odrzucenie 18 pierwszych sur Koranu ${ }^{159}$. Z następnymi (od 19 do 36) autor nie polemizuje, ograniczając się do stwierdzenia, że są równie szarlatańskie, jak poprzednie ${ }^{160}$. Kolejne rozdziały Niketas poświęcił rozwinięciu argumentacji w konkretnych sprawach, takich jak pochodzenie Arabów od Izmaela, pozycja Chrystusa względem Boga czy życie płciowe aniołów ${ }^{161}$.

Nie wszyscy antyislamscy polemiści byli równie wyrafinowani jak Niketas. Zdarzały się także teksty na znacznie niższym poziomie. Tak jest w przypadku listu przypisywanego Aretasowi ${ }^{162}$. Wartość teologiczna tego tekstu jest oceniana przez badaczy bardzo nisko ${ }^{163}$. To między innymi sprawia, że autorstwo Aretasa poddawane jest w wątpliwość, a tekst postrzegany jako niegodny wielkiego teologa ${ }^{164}$. W opinii Patricii Karlyn-Hayter list był napisany dla szerokiego grona niewykształconych chrześcijańskich odbiorców i miał charakter dziełka propagandowego ${ }^{165}$.

Jeśli przyjmiemy, że Aretas jest autorem listu, to musiał on zostać napisany około roku 920-922 ${ }^{166}$. Zakładając, że list był odpowiedzią na rzeczywiście przysłane do Bizancjum pismo, trzeba zapytać, kto mógł być inicjatorem wymiany korespondencji. W świetle cytowanego źródła był to emir Damaszku, ale równocześnie wezyr, a list został wysłany z Emet ${ }^{167}$. Trudności nastręcza zarówno pogodzenie wspomnianych tytułów (w X w. emir raczej nie mógł nosić tytułu wezyra), jak i ustalenie o jaką miejscowość chodzi ${ }^{168}$. Patricia Karlyn-Hayter skłonna jest sądzić, że korespondencję zainicjował Takin al-Khazari († 933), najpierw emir Egiptu, a potem Damaszku ${ }^{169}$.

Koranu i wykorzystania ich w chrześcijańskich apologiach, por. S.H. Griffith, The Qur'an in Arab Christian Texts: the Developpement of an Apologetical Argument: Abu Qurrah in the Maglis of alMa'mun, ParOr 24 (1999) 203-233.

${ }^{159}$ Por. Nicetas Byzantinus, Confutatio dogmatum Mahomedis I 26 - XVII 76, PG 105, 701D - 768B.

${ }^{160}$ Por. tamże XVIII 77, PG 105, 768B-D.

${ }^{161}$ Por. tamże XVIII 78 - XXX 106, PG 105, 768D - 805D. Również Teofanes (Chronographia, rec. Classenus, vol. 1, CSHB 32, 511, 18 - 512, 7) uznał za konieczne przybliżenie genealogii przywódcy Saracenów, którą tradycyjnie wywiódł od Izmaela.

${ }^{162}$ Por. nota 17.

${ }^{163}$ Por. Karlyn-Hayter, Arethas's Letter, s. 282-283.

${ }^{164}$ Zdania są krótkie, brak cytatów i subtelnych aluzji, por. tamże, s. 283-284.

${ }^{165}$ Por. tamże, s. 286.

${ }^{166}$ Por. tamże, s. 285. Inaczej A. Abel (La lettre polémique, s. 352), który wskazuje na lata 939940. W jego opinii list został napisany w czasie trwania ekspedycji Hammanidów przeciw Armenii.

${ }^{167}$ Por. Arethas, Epistula ad Amiram Damascenum missa, ed. Karlyn-Hayter, s. 293. Niewiele wiadomo o treści listu emira. A. Abel (La lettre polémique, s. 347-349) próbuje odtworzyć ją w zarysie na podstawie podobnych przykładów.

${ }^{168} \mathrm{~W}$ opinii A. Abela (La lettre polémique, s. 345) chodzi o Amidę, z czym nie zgadza się P. Karlyn-Hayter (Arethas's Letter, s. 286-290).

${ }^{169}$ Por. Karlyn-Hayter, Arethas's Letter, s. 288-290. A. Abel (La lettre polémique, s. 345), biorąc 
Aretas sądził, że istnieją dwie księgi, będące wykładnią wiary muzułmanów (Koran i Forgan) ${ }^{170}$. Przekłamywał - trudno orzec czy celowo, czy z braku wiedzy - świadectwa Koranu na temat poczęcia i narodzin Jezusa ${ }^{171}$. Popełnił także wiele innych błędów - źle podał imię Zayda ibn al-Khattaba († 632), przyjaciela Mahometa, a na dodatek nazwał go „Rousouloule” (= Rasûl Allah), który to tytuł przysługiwał samemu prorokowi ${ }^{172}$.

Niezależnie od poziomu intelektualnego, wiedzy i umiejętności literackich poszczególnych autorów, używali oni podobnych argumentów. Dla wszystkich, którzy zagłębili się w lekturę pism, szybko musiało stać się jasne, że Biblia i Koran są nie do pogodzenia. W szczególności przedmiotem sporu były dogmaty o wcieleniu i Trójcy Świętej ${ }^{173}$. Stopniowo w kręgach chrześcijańskich uświadamiano sobie, że islam to nie herezja Izmailitów, jak sądził jeszcze Jan z Damaszku, lecz odmienna religia. Sprzyjały temu dwa sprzeczne zjawiska: zarówno coraz liczniejsze konwersje na islam, jak i trwanie wspólnot chrześcijańskich na ziemiach islamskich ${ }^{174}$.

Dlatego chrześcijańscy polemiści skoncentrowali się na zwalczaniu nowej religii i na obronie dogmatów chrześcijańskich. Wśród tematów, które poruszano najczęstsze były, poza wspomnianymi powyżej dogmatami, kwestie uznania Mahometa za proroka, status Koranu i Ewangelii, ich wiarygodność, różnice w praktykach prawnych i zwyczajach religijnych. Podczas gdy polemiści chrześcijańscy podważali wartość Koranu, według autorów arabskich fragmenty Pisma Świętego, które wspierały nauczanie chrześcijańskie w tych kwestiach zostały sfałszowane ${ }^{175}$. Jak podkreśliła Sandra Keating Toenies, wiele z poruszanych zagadnień nie było dla chrześcijan nowych. Od dawna mierzyli się z podobnymi zarzutami, wysuwanymi przez Żydów (absolutny monoteizm, problem wcielenia) ${ }^{176}$. Do tych zagadnień doszły jednak nowe.

Chrześcijańscy polemiści starali się wytłumaczyć doktrynę wcielenia i TrójcyŚwiętej muzułmanomiswoim współwyznawcom, udowadniając, żeniepozostają one w sprzeczności z monoteizmem. Czynili tak na przykład Abū Rā'iṭah ${ }^{177}$

pod uwagę tytuł wezyra uważa, że list wysłano w imieniu kalifa. Przypuszcza (tamże, s. 351), że napisał go Ibn Al-Rā'īq.

${ }^{170}$ Por. Arethas, Epistula ad Amiram Damascenum missa, ed. Karlyn-Hayter, s. 293. Faktycznie arabskie słowo Furqān oznaczało Koran, por. Abel, La lettre polémique, s. 256, nota 2.

${ }^{171}$ Por. Arethas, Epistula ad Amiram Damascenum missa, ed. Karlyn-Hayter, s. 294-295.

${ }^{172}$ Por. tamże, ed. Karlyn-Hayter, s. 297.

${ }^{173}$ Por. Keating, Defending the „People of the Truth”, s. 5; Sadowski, Chrześcijańska arabskojęzyczna literatura, s. 100-104.

${ }^{174}$ Por. Keating, Defending the „People of the Truth”, s. 5-6.

${ }^{175}$ Por. tamże, s. 8-9; Sadowski, Chrześcijańska arabskojęzyczna literatura, s. 95-97.

${ }^{176}$ Por. Keating, Defending the „People of the Truth”, s. 7.

177 Świetnym przykładem jest Abū Rā’ițah, którego teksty poświęcone zostały udowodnieniu prawdziwości religii chrześcijańskiej i Trójcy Świętej - por. teksty tego autora publikowane przez S.T. Keating (Defending the „People of the Truth, s. 82-137, 164-215 i 222-297). Bartłomiej z Edessy (Elenchus et confutatio Agareni, PG 104, 1393-1404) dużo miejsca poświęcił rozważaniom nad 
i Aretas ${ }^{178}$. Ten ostatni pisząc o Chrystusie, Synu i Słowie Bożym, powoływał się na ciekawą paralelę ze słońcem, które wysyła promienie różnie określane przez ludzi, lecz przecież $\mathrm{w}$ istocie będące tym samym ${ }^{179}$. Na zarzuty muzułmanów, że chrześcijanie oddają cześć krzyżowi odpowiadał, że muzułmanie czczą płaszcz Mahometa ${ }^{180}$. Ten ostatni zarzut nie jest słuszny, bowiem przedmioty należące do Proroka nigdy nie były relikwiami.

Polemiści przeciwstawiali koncepcję wolnej woli idei predestynacji, którą odnajdowali w Koranie ${ }^{181}$. Jerzy Mnich i Bartłomiej z Edessy czynili wyznawcom islamu zarzut $\mathrm{z}$ tego, iż uznając Boga za przyczynę wszystkich rzeczy, czynią go odpowiedzialnym także za wszelkie zło, widzą w Nim stwórcę rozbójników i czarowników ${ }^{182}$. Autorzy chrześcijańscy krytykowali, jako pogański, kult Kaaby i użycie pluralis (my) w Koranie.

Chrześcijanie atakowali w pierwszym rzędzie założyciela islamu. Wypominano mu, że był czcicielem idoli ${ }^{183}$. Mahomet był przedstawiany jako fałszywy prorok, który nie otrzymał misji bezpośrednio od Boga (jak np. Mojżesz). Wskazywano, że nie było naocznych świadków, którzy mogliby potwierdzić jego objawienia i że żadne przepowiednie nie zapowiadały jego pojawienia się ${ }^{184}$. Gdy okazało się, że w rzeczywistości w Koranie znajdują odwołania do Biblii, zapowiadającej nadejście Mahometa ${ }^{185}$, ściągnęło to na muzułmanów zarzuty o fałszowanie Pisma. Sposobem kwestionowania nauk tego ostatniego było też wypominanie mu, iż nie czynił cudów, zatem nie dawał znaków

Chrystusem-Słowem Bożym. Również Teodor Abu Kurra (Opuscula ascetica XXIII, PG 97, 1553C - 1556A; tamże XXV, PG 97, 1557D - 1561D; tamże XXXII, PG 97, 1583A - 1584C) udowadniał, że Chrystus był Synem Bożym i Bogiem. Z kolei Al-Kindi (Risālat I 1-2) poświęcił znaczną część swego dzieła udowadnianiu, że jego przodkowie czcili Jedynego Boga i że idea Trójcy Świętej nie jest sprzeczna z monoteizmem. Równie wiele miejsca Al-Kindi poświęcił Chrystusowi (tamże II 3, 11-13; III 10, 1-61). Por. Muir, The Apology of Al Kindy, s. 110-119; Keating, Defending the „People of the Truth", s. 11.

${ }^{178}$ Por. Arethas, Epistula ad Amiram Damascenum missa, ed. Karlyn-Hayter, s. 296. Wskazywał równocześnie, że chrześcijanie w przeciwieństwie do muzułmanów nie umrą w grzechu.

${ }^{179}$ Por. tamże.

${ }^{180}$ Por. tamże, ed. Karlyn-Hayter, s. 297.

${ }^{181}$ Por. Georgius Monachus, Chronicon, ed. de Boor, vol. 2, s. 701 (= PG 110, 872A). Zob. Bartholomaeus Edessenus, Elenchus et confutatio Agareni, PG 104, 1393B.

${ }_{182}$ Por. Georgius Monachus, Chronicon, ed. de Boor, vol. 2, s. 701 (= PG 110, 872A). Zob. Bartholomaeus Edessenus, Elenchus et confutatio Agareni, PG 104, 1393B.

${ }^{183}$ Por. Al-Kindi, Risālat II 3, 12. Zob. Muir, The Apology of Al Kindy, s. 41-43.

${ }^{184}$ Argumenty takie podnosiła większość polemistów, m.in. Joannes Damascenus, De haeresibus 3, 3-5. 34-37, SCh 383, 214-216, ŹMT 59, 135-136; Theodorus Abucara, Opuscula ascetica XIX, PG 97, 1544A - 1545A. Jan z Damaszku wskazywał, że Mahomet zakazywał muzułmanom czynić cokolwiek bez świadków, a sam takowego nie mógł przedstawić. Argumenty te powtarzali późniejsi autorzy. Szerzej na ten temat, por. Khoury, Polémique byzantine contre l'Islam, s. 22-23, 29-30 i 105-109.

${ }^{185}$ Por. Al-Qur'ān sura II 129; sura VII 157; sura LXI 6. 
nadnaturalnego pochodzenia swej misji ${ }^{186}$. Silnie tę różnicę między Mahometem a Jezusem podkreślał Aretas ${ }^{187}$. Według niego grób Mahometa jest ciemny w przeciwieństwie do grobu Chrystusa ${ }^{188}$. Znacznie inteligentniejszy od autora listu Aretasa Abu Kurra używał logiki, by pokonać oponentów, odwoływał się do rozumu, ale także przywoływał cuda, jako dowód słuszności religii chrześcijańskiej ${ }^{189}$.

Zarzut braku cudów był absurdalny, bowiem pierwotnie, zgodnie z tradycją koraniczna, Mahomet miał jedynie przekazać ludziom posłannictwo Boga. Wsparcie Allaha dla jego proroka nie wyrażało się obdarzeniem go nadnaturalnymi zdolnościami. Jednak wkrótce po śmierci Mahometa jego wizerunek zaczął się zmieniać, zapewne także pod wpływem chrześcijańskiej krytyki. Jak ujął to Adel-Théodore Khoury - „la théologie musulmane islamisait Jésus, en même temps que la piété des musulmans christianisait Mahomet"190. Było to spowodowane dostrzeżeniem, jakim prestiżem cieszyli się Mojżesz i Jezus w oczach Mahometa, co znalazło odzwierciedlenie w Koranie. Pierwszym, który uznał cuda za dowód wiarygodności misji prorockiej był Abu Kurra ${ }^{191}$. Obszerną debatę z tradycją muzułmańska, przypisującą Mahometowi uczestnictwo lub sprawstwo cudownych wydarzeń znajdujemy u Bartłomieja z Edessy ${ }^{192}$.

Wskazywano także, że wiele faktów z życia Mahometa dowodzi, że nie posiadał daru prorockiego, nie przewidział wielu zdarzeń, także tych, które

${ }^{186}$ Por. Al-Kindi, Risālat II 4, 1-123. Zob. Muir, The Apology of Al Kindy, s. 55-64; Khoury, Polémique byzantine contre l'Islam, s. 42-58.

${ }^{187}$ Por. Arethas, Epistula ad Amiram Damascenum missa, ed. Karlyn-Hayter, s. 297.

${ }^{188}$ Por. tamże, ed. Karlyn-Hayter, s. 298. A. Abel (Le caractère sociologique du „,culte” de Mahomet dans l'Islam tardif, w: Mélanges Georges Smets, Bruxelles 1952, 51-52) wykazał, że zgodnie z tradycją muzułmańską było przeciwnie - z grobu Mahometa wznosiła się świetlna kolumna. Aretas (Epistula ad Amiram Damascenum missa, ed. Karlyn-Hayter, s. 299-300) zwalczał też opinię, że Jezue ben Nawn, który wstrzymał słońce, był równy Chrystusowi, bowiem uczynił to dla celów praktycznych (wojskowych), natomiast na ukrzyżowanie Chrystusa samo słońce zareagowało zaćmieniem.

${ }^{189}$ Por. Nassif, Religious Dialogue in the Eight Century, s. 335-336.

${ }^{190}$ Khoury, Polémique byzantine contre l'Islam, s. 43.

${ }^{191}$ Por. Theodorus Abucara, Opuscula ascetica XVIII (= Joannes Damascenus, Disceptatio Christiani et Saraceni), PG 94, 1596B - 1597C.

${ }_{192}$ Por. Bartholomaeus Edessenus, Elenchus et confutatio Agareni, PG 104, 1389B - 1393A (Mahomet nie czynił cudów, brak świadków). Tamże, PG 104, 1432A-D, 1433A-B i 1440C - 1441B (wyśmiewanie cudów przypisywanych Mahometowi). Jednym z nich miała być podróż proroka do nieba i rozmowa z Bogiem (jedynym świadkiem - Fatima). Innym - nieudana próba wskrzeszenia klaczy. Bajkowość tych opowieści wynika w dużej mierze z faktu, że Bartłomiej wykorzystał liczne legendarne opowieści, zarówno islamskie, jak i chrześcijańskie (por. Argyriou, Perception de l'Islam, s. 31; Khoury, Polémique byzantine contre l'Islam, s. 51-53). Na temat mitycznej podróży proroka, zob. A. Bevan, Mohammed's Ascension to Heaven, w: Studien zur semitischen Philologie und Religionsgeschichte Julius Wellhausen zum siebzigsten Geburtstag am 17. Mai 1914 gewidmet von Frenden und Schülern, hrsg. K. Marti, Beihefte zur Zeitschrift für die Alttestamentliche Wissenschafte 27, Giessen 1914, 51-61; J. Horowitz, Die Muhammeds Himmelfahrt, „Islam” 9 (1919) 159-183. 
dotyczyły jego i jego bliskich - polemiści wskazywali przykłady zaczerpnięte ze źródeł biograficznych, nie muzułmańskich wszakże, lecz nestoriańskich (opowieści muzułmańskie traktowali jako czyste wymysły) ${ }^{193}$. Bartłomiej konstatował, że Mahomet nie był ani prorokiem ani posłańcem ${ }^{194}$. Objawienia Mahometa próbowano tłumaczyć w sposób zarazem racjonalny i uwłaczający prorokowi. Teofanes wiedział, że Mahomet powoływał się na przesłanie od Boga, które miał otrzymać za pośrednictwem archanioła Gabriela, ale negował taką możliwość. Twierdził, że Saracen chorował na epilepsję, co bardzo smuciło i niepokoiło jego małżonkę. Aby wytłumaczyć ataki choroby, miał powiedzieć Chadżidży (ok. 555 - ok. 620), że ma wizje, które powodują nagłe przypadki utraty świadomości. Żona nie od razu mu uwierzyła, ale gdy jego wiarygodność potwierdził znajomy mnich, wygnany (z Bizancjum?) z powodu nieprawomyślnych poglądów, zaczęła opowiadać kobietom ze swego plemienia, że mąż jest prorokiem. Nowa wiara (herezja wg Teofanesa) zaczęła się rozprzestrzeniać, najpierw w sekrecie, potem na drodze wojny, wreszcie otwarcie. Wszystko to trwać miało w sumie 29 lat ${ }^{195}$. Według innej wersji archanioł po prostu przyśnił się Mahometowi ${ }^{196}$, a ten uznał sen za rzeczywistość. W najbardziej skrajnej interpretacji to demony dręczyły Mahometa ${ }^{197}$.

Niketas polemizował ze stwierdzeniem, że Biblia zapowiada Mahometa ${ }^{198}$. Również Aretas starał się podkreślić różnice między chrześcijaństwem a islamem, dlatego rozwodził się nad prorokami, którzy przepowiedzieli nadejście Jezusa $^{199}$, podczas gdy Mahometa nikt nie zapowiada ${ }^{200}$.

Obecność w nauczaniu Mahometa elementów staro- i nowotestamentowych tłumaczono tym, że swe nauki zaczerpnął od Żydów i od chrześcijan-heretyków

${ }^{193}$ Por. Bartholomaeus Edessenus, Elenchus et confutatio Agareni, PG 104, 1389B-C i 1420A. Zob. Khoury, Polémique byzantine contre l'Islam, s. 40. Bartłomiej wiedział o 4 synach Mahometa i córce Fatimie (tamże, PG 104, 1420D - 1421A). W rzeczywistości mamy poświadczone jeszcze 3 inne córki proroka (H. Lammens, Fatima et les filles de Mahomet, Rome 1912, 3-7), natomiast spośród synów pewny jest jedynie Ibrahim.

${ }^{194}$ Por. Bartholomaeus Edessenus, Elenchus et confutatio Agareni, PG 104, 1389A. Zob. Argyriou, Perception de l'Islam, s. 30-32.

${ }^{195}$ Por. Theophanes, Chronographia, CSHB 32, 513, 14-16. Podobną opowieść w skróconej wersji znajdziemy u Jerzego Mnicha (Chronicon, ed. de Boor, vol. 2, s. 698-699 [= PG 110, 865B-C]). O epilepsji wspomina także Bartłomiej z Edessy (Elenchus et confutatio Agareni, PG 104, 1428B).

${ }^{196}$ Por. Joannes Damascenus, De haeresibus 3, 20-21, SCh 383, 214, ŹMT 59, 136. Zob. Khoury, Polémique byzantine contre l'Islam, s. 79. Demetrios J. Constantelos (The Moslem Conquest, s. 353) sądzi jednak, że Abu Kurra był „less polemical against Islam” niż Jan z Damaszku.

${ }^{197}$ Por. Theodorus Abucara, Opuscula ascetica XX, PG 97, 1545A - 1548A. Zob. Khoury, Polémique byzantine contre l'Islam, s. 79.

${ }_{198}$ Por. Nicetas Byzantinus, Confutatio dogmatum Mahomedis XVIII 79, PG 105, 769B - 772B. Zob. Khoury, Polémique byzantine contre l'Islam, s. 31-32.

${ }^{199}$ Por. Arethas, Epistula ad Amiram Damascenum missa, ed. Karlyn-Hayter, s. 293-295.

${ }^{200}$ Por. tamże, ed. Karlyn-Hayter, s. 297. 
w czasie swych podróży w interesach, gdy pracował dla Chadżidży ${ }^{201}$. Opowiadano, że pewien heretycki mnich nauczał Mahometa ${ }^{202}$. Nie było jednak zgody, kim był - według jednych arianinem ${ }^{203}$, według innych nestorianinem i hezychasta ${ }^{204}$. Jego wpływem thumaczono wyobrażenia Mahometa na temat Chrystusa, które zwykle oceniano jako nestoriańskie, chociaż Anastazy Synaita dostrzegł związek między wierzeniami muzułmanów, a monofizytyzmem $^{205}$. Według Niketasa z Bizancjum wśród źródeł, z których korzystał Mahomet, były też przekazy ariańskie i manichejskie (manicheizm funkcjonował jako synonim herezji szczególnie niebezpieczneje6). Proroka oskarżano, że dokonał fałszerstwa Biblii, głosi kult demona, jest poganinem ${ }^{207}$, wprowadza kult Szatana, jest magiem, szarlatanem ${ }^{208}$.

Atakowano nie tylko naukę Mahometa, ale także jego osobiście. Twierdzono, że był synem niewolnicy, Aminy ( $†$ 577), za to może nie był nawet synem Abd Allaha (ok. 545-570) ${ }^{209}$. Wypominano mu, że był sierotą bez środków do życia, a swe bogactwo zawdzięczał kobiecie ${ }^{210}$. Jak ujął to Teofanes,

${ }^{201}$ Por. Theophanes, Chronographia, CSHB 32, 512, 10-18; Georgius Monachus, Chronicon, ed. de Boor, vol. 2, s. 699-700 (= PG 110, 865A-B).

${ }^{202}$ Występuje on w źródłach pod imieniem imieniem Bahīāā, czasem Sergiusza Bahīrā. Opowieść o chrześcijaninie, który rozpoznał w Mahomecie proroka najpierw pojawiła się w źródłach muzułmańskich. Dopiero później została rozwinięta w pismach autorów chrześcijańskich, którzy zmienili jej wydźwięk. Szerzej na ten temat por. B. Roggema, The Legend of Sergius Bahīrā. Eastern Christians Apologies and Apokalyptic in Responce to Islam, Leiden - Boston 2009; S. Gero, The Legend of the Monk Bahīrā, the Cult of the Cross and Iconoclasm, w: La Syrie de Byzance, s. 4758; A. Bahkou, The Christian Legend of Monk Bahīrā. The Syriac Manuscript of Mardin 259/2: Study and English Translation, artykuł (bez przekładu) dostępny na stronie http://www.baylorisr. org/wp-content/uploads/bahkou_monk.pdf. [dostęp: 15. 10.2014]. Tam czytelnik znajdzie odesłania do dalszej, bardzo obszernej literatury.

${ }^{203}$ Tak sądzili: Jan z Damaszku i Teodor Abu-Kurra.

${ }^{204}$ Por. Bartholomaeus Edessenus, Elenchus et confutatio Agareni, PG 104, 1389D, 1396C i 1428A. U Bartłomieja mnich występuje pod imieniem Pachura. Później uznawano go też za astronoma, czy też astrologa, por. Euthymius Zigabenus, Disputatio de fide cum philosopho saraceno in urbe Melitene 13, PG 131,33D - 36A.

${ }^{205}$ Por. Tolan, Réactions chrétiennes, s. 354-355.

${ }^{206}$ Por. Khoury, Polémique byzantine contre l'Islam, s. 356.

${ }^{207}$ Por. Nicetas Byzantinus, Confutatio dogmatum Mahomedis I 3, PG 105, 716A i 717A; tamże I 40, PG 105, 721D - 724A; tamże II 43, PG 105, 728B-D; Theodorus Abucara, Opuscula ascetica XX, PG 94, 1545A - 1548A. Por. Khoury, Polémique byzantine contre l'Islam, s. 101-102.

${ }^{208}$ Por. Nicetas Byzantinus, Confutatio dogmatum Mahomedis I 28, PG 105, 705C; tamże I 38, PG 105, 721A; tamże XXV 94, PG 105, 792B; tamże XXVII 98, PG 105, 796C-D; tamże XXX 106, PG 105, 805C. Zob. Khoury, Polémique byzantine contre l'Islam, s. 131.

${ }^{209}$ Bartłomiej z Edessy (Elenchus et confutatio Agareni, PG 104, 1424D - 1425C) barwnie opisywał, jak dziadek Mahometa wybrał się z jego ojcem na targ, by wybrać dla niego niewolnicę, jak ta pasła wielbłądy i zaszła w ciążę, nie wiadomo, czy z Abd Allahem, czy z którymś z pastuchów. Mahomet miał urodzić się na pastwisku i zostać przyniesiony do domu przez matkę na wielbłądzim nawozie. Por. Khoury, Polémique byzantine contre l'Islam, s. 65.

${ }^{210}$ Por. Bartholomaeus Edessenus, Elenchus et confutatio Agareni, PG 104, 1425C-D; Theo- 
Mahomet pracował u bogatej wdowy Chadżidży, prowadząc karawany między Palestyną i Egiptem. Następnie poślubił jac, wchodząc tym samym w posiadanie jej majątku ${ }^{211}$. Zgłaszano wiele zastrzeżeń do jego moralności, zarzucając mu grzeszność, brak lojalności i fałsz, rozwiązłość, krwiożerczość, brak wiedzy (wykształcenia), bezbożność ${ }^{12}$. Chrześcijańscy polemiści powszechnie twierdzili, że nie zachowywał się wystarczająco godnie, jak przystało wysłannikowi Boga ${ }^{213}$. Aretas podawał, jako przykład niemoralnego zachowania Mahometa, odebranie przezeń żony jego przyjacielowi, Zaydowi ${ }^{214}$. Ten sam zarzut, poszerzony o wypomnienie licznych małżonek, postawił Al-Kindi ${ }^{215}$.

Podkreślano, że w przeciwieństwie do Chrystusa Mahomet nie zmartwychwstał, lecz spoczywa pod stopami modlących się muzułmanów ${ }^{216}$. Al-Kindi negował prawdziwość opowieści, że na tronie Bożym zapisane jest jego imię 217 . Bartłomiej z Edessy popisywał się swą wiedzą na temat pochodzenia Mahometa, wypominając wyznawcom jego religii, że niewiele o nim wiedzą ${ }^{218}$. W swym dziele zawarł długą listę przodków, żon i dzieci Proroka ${ }^{219}$. Przytoczył też opowieści o jego przodkach, stawiające ich w złym świetle ${ }^{220}$.

Kolejnym obiektem ataków chrześcijańskich polemistów był Koran, przedstawiany jako fałszywe Pismo. Zdaniem Niketasa Koran nie był dziełem Boga, lecz demona, kompilacją różnych tekstów, często sprzecznych. Bizantyńczyk oceniał go jako budowlę wzniesioną bez planu, nie wykorzystującą wiedzy ludzkiej ${ }^{221}$. Poszczególne sury są określane przez Niketasa bądź mianem bajeczki ( $\mu v \theta \alpha ́$ pıov), bądź mianem fantastycznej (mitycznej) opowieści ( $\mu v \theta 0 \varepsilon \pi \varepsilon i ́ \alpha$,

phanes, Chronographia, CSHB 32, 512, 10-16; Georgius Monachus, Chronicon, ed. de Boor, vol. 2, s. 698 (= PG 110, 865A-B). Późniejsi autorzy ubarwiali opowieść, opisując nędzny wygląd Mahometa i jego równie nędzną egzystencję w dzieciństwie (por. Bartholomaeus Edessenus, Contra Muhammed, PG 104, 1448C). Z powodu jego wyglądu Chadżidża miała nie chcieć z nim sypiać (por. tamże, PG 104, 1448D - 1449A).

${ }^{211}$ Por. Theophanes, Chronographia, CSHB 32, 512, 10-13.

${ }^{212}$ Por. Khoury, Polémique byzantine contre l'Islam, s. 87-102.

${ }^{213}$ A.-Th. Khoury (Polémique byzantine contre l'Islam, s. 59-102) omawia żywot Mahometa, nakreślony przez wrogów islamu, szczególnie jego sylwetkę moralną (tamże, s. 87-102).

214 Por. Arethas, Epistula ad Amiram Damascenum missa, ed. Karlyn-Hayter, s. 297-298. W opowieści Aretasa odnajdujemy dalekie echo sury XXXIII, w. 37-38.

${ }^{215}$ Por. Al-Kindi, Risālat III 3, 111-148. Zob. Muir, The Apology of Al Kindy, s. 51-53.

${ }^{216}$ Por. Bartholomaeus Edessenus, Elenchus et confutatio Agareni, PG 104, 1412C; Al Kindi, Risālat II 5, 1-117. Zob. Muir, The Apology of Al Kindy, s. 62-63.

${ }^{217}$ Por. Muir, The Apology of Al Kindy, s. 88-89.

${ }^{218}$ Por. Bartholomaeus Edessenus, Elenchus et confutatio Agareni, PG 104, 1416D - 1417A.

${ }^{219}$ Por. tamże, PG 104, 1417D - 1421A. W innym miejscu wypomniał Mahometowi, że miał 10 żon i 16 nałożnic (por. tamże, PG 104, 1388B).

${ }^{220}$ Jego dziad walczył ze swym bratem (por. tamże, PG 104, 1421C - 1424C).

${ }^{221}$ Por. Nicetas Byzantinus, Confutatio dogmatum Mahomedis I 26, PG 105, 704A. Zob. Argyriou, Perception de l'Islam, s. 35. 
$\mu v \theta o \lambda o \gamma i \alpha, \mu v \theta o \pi \lambda \alpha \sigma \tau i \alpha, \mu \hat{v} \theta o \varsigma)^{222}$. Z kolei Al-Kindi dowodził, że Koran nie jest dziełem oryginalnym ${ }^{223}$. $Z$ porównania jego tekstu $\mathrm{z}$ tekstem Biblii wyciągano wniosek, że zawiera on wiele błędów w kwestii postaci biblijnych.

Zakwestionowawszy Koran i poddawszy gruntownej krytyce Mahometa wyciagano wnioski odnoszące się do islamu jako całości. Uznano go za religię fałszywą, czego dowodzić miał fakt, że zawiera sprzeczności, których prawdziwa religia mieć nie może, bowiem musi być koherentna. Podkreślano, że jego praktyki nie dają szans na zbawienie i nie proponuje ona wyższej moralności niż inne religie. Odrzucano głoszoną przez muzułmanów tezę o następstwie form religijnych, zgodnie z którą po judaizmie przyszło chrześcijaństwo, a po nim islam ${ }^{224}$.

Podkreślano zasadniczą różnicę w sposobie rozpowszechniania chrześcijaństwa i islamu - to pierwsze zyskiwało wyznawców mocą własnego przekazu, ten drugi - dzięki użyciu siły. Już Żyd Abraham w Doctrina Jacobi nuper baptizati uznał fakt, że Mahomet przybył z mieczem i armią za dowód, iż nie był on prawdziwym prorokiem ${ }^{225}$. Al-Kindi opisywał wojenne działania muzułmańskiego proroka ${ }^{226}$, zaznaczając, że zwycięstwa nie są dowodem posiadania racji ${ }^{227}$. Wyznawcom islamu zarzucano, że wspierają zachowania agresywne, obiecując raj tym, którzy zabijają wrogów ${ }^{228}$. W drugim liście muzułmanina do cesarza Michała miało znajdować się twierdzenie, że islam jest religią doskonałą i że muzułmanie mają prawo zabijać tych, którzy nie przyjmują religii proroka ${ }^{229}$.

Uderzając $\mathrm{w}$ islam wykorzystywano chętnie zarzuty dotyczące spraw obyczajowych. Już wspomniano wyżej o Janie z Damaszku, który oskarżał muzułmanów o dokonywanie obrzezania kobiet ${ }^{230}$. Ten sam zarzut spotykamy także u innych polemistów, między innymi u Al-Kindiego, który wszakże wykazywał się znacznie lepszym rozeznaniem w kwestiach obyczajów i prawa islamskiego ${ }^{231}$. Niechęć wzbudzało dopuszczone przez islam wielożeń-

222 Por. MvӨópırov: Nicetas Byzantinus, Confutatio dogmatum Mahomedis XII 68, PG 105, 757A; XIII 70, PG 105, 760C; XIV 71, PG 105, 761A; XV 72, PG 105, 761B; XVI 73, PG 105, 761D; XVII 76, PG 105, 765C; XVIII 77, PG 105, 768B; XVIII 81, PG 105, 773A; XVIII 82, PG

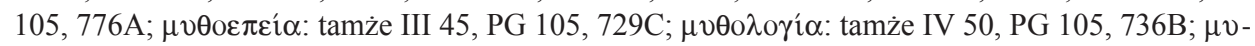

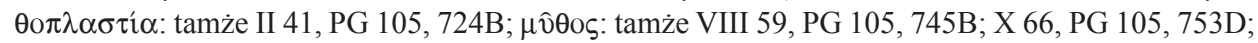
XI 67, PG 105, 756D; XVIII 79, PG 105, 769B; XVIII 80, PG 105, 772B.

${ }^{223}$ Por. Muir, The Apology of Al Kindy, s. $79-84$ (są w nim obce słowa!). Al Kindi wiele uwagi poświęcił świętej księdze islamu (Al-Kindi, Risālat II 6, 59-169).

${ }^{224}$ Por. Khoury, Polémique byzantine contre l'Islam, s. 45.

${ }^{225}$ Por. Doctrina Jacobi nuper baptizati V 16, ed. Deroche, s. 209-210.

${ }^{226}$ Por. Al-Kindi, Risālat II 3.

${ }^{227}$ Por. tamże II 5, 65-80 (porównał Mahometa do Nabuchodonozora).

${ }^{228}$ Por. Georgius Monachus, Chronicon, ed. de Boor, vol. 2, s. 705 (= PG 110, 872A).

${ }^{229}$ Por. Argyriou, Perception de l'Islam, s. 33-34.

${ }^{230}$ Por. Joannes Damascenus, De haeresibus 8, 7, SCh 383, 226, ŹMT 59, 139.

${ }^{231}$ Por. Al-Kindi, Risālat III 9, 37-346. Por. Muir, The Apology of Al Kindy, s. 90-43; The Early 
stwo i pozycja kobiet w tej religii (kobiety jako ,pole uprawne" 232 w Koranie). Krytykowano wielożeństwo i inne niestosowne czyny ${ }^{233}$, nie zawsze słusznie interpretując prawo koraniczne ${ }^{234}$.

Spośród zasad wiary głoszonych przez Mahometa uwagę autorów chrześcijańskich przykuwała idea raju, płynącego mlekiem, winem i miodem, gwarantującego nieustanne rozkosze z kobietami, do którego wstęp mieć mieli ci, którzy zabiją wroga lub zginą w walce ${ }^{235}$. Szczególnie Aretas krytykował muzułmańskie wyobrażenie raju w którym, według jego wiedzy, każdy muzułmanin miał mieć do dyspozycji 7 rumaków i 7 kobiet, wiecznych dziewic, a pożywienie zapewniać mu miały rzeki mleka, miodu i wina ${ }^{236}$.

W miarę, jak chrześcijanie poznawali muzułmańskie obyczaje, także one stawały się przedmiotem krytyki. Bartłomiej z Edessy poszedł szczególnie daleko bezlitośnie wykpiwając zarówno rytuały życia codziennego jak i modlitwy islamskie (w szczególności zwyczaj obmywania się wodą lub piaskiem) ${ }^{237}$.

Zapewne po to, by powstrzymać nawrócenia na islam, stawiano pod znakiem zapytania łatwość, z jaką nową religię przyjmowali sami Arabowie. Bartłomiej z Edessy wskazywał przykłady oporu wobec próby nawrócenia wyznawców dawnych kultów, w szczególności czcicieli Gwiazdy Porannej, utożsamianej z Afrodytą ${ }^{238}$. W polemikach wykorzystywano fakt, że skutkiem oporu wobec posłannictwa Mahometa była ucieczka do Medyny.

Jak wynika z powyższych, dalece niepełnych, lecz reprezentatywnych danych ${ }^{239}$, chrześcijanie nie od razu podjęli próbę skonfrontowania się z nowym wyzwaniem, jakim było dla nich pojawienie się konkurencyjnej religii monoteistycznej. Początkowo nie zdawali sobie sprawy ze zmian, jakie zaszły na Półwyspie Arabskim i najeźdźców traktowali po prostu jako żądnych łupów koczowników. Nie znali ich religijnych poglądów i nie bardzo mieli jak je po-

Christian-Muslim Dialog, s. 731nn. Chrześcijański polemista twierdził, że rytuały były pochodzenia pogańskiego (Al-Kindi, Risālat III 9, 105-117.

${ }^{232}$ Al-Qur'ān sura II 223 (cytat w przekładzie J. Bielawskiego).

${ }^{233}$ Por. Arethas, Epistula ad Amiram Damascenum missa, ed. Karlyn-Hayter, s. 293.

${ }^{234}$ Aretas nie zrozumiał, że Koran chroni kobietę, która została odtrącona przez męża, dając jej prawo do poślubienia innego (Al-Qur'ān sura II 232).

235 Por. Theophanes, Chronographia, CSHB 32, 513, 17 - 514, 6; Bartholomaeus Edessenus, Contra Muhammed, PG 104, 1456C-1457A. Jerzy Mnich [Chronicon, ed. de Boor, vol. 2, s. 700 (= PG 110, 868B-C)] dodał, że Mahomet miał dzierżyć klucze raju.

${ }^{236}$ Por. Arethas, Epistula ad Amiram Damascenum missa, ed. Karlyn-Hayter, s. 300-301. Złośliwie stwierdzał, że ci, którzy muszą jeść, muszą też wydalać. Za Aretasem powtórzył to Niketas Choniates.

${ }^{237}$ Por. Bartholomaeus Edessenus, Elenchus et confutatio Agareni, PG 104, 1405A - 1408A.

${ }^{238}$ Por. tamże, PG 104, 1436B - 1437A.

${ }^{239}$ Ograniczenia narzucane formą artykułu sprawiły, że byłam zmuszona dokonać selekcji i zrezygnować z bardziej szczegółowego omawiania tez poszczególnych autorów. 
znać wobec braku pism muzułmańskich. Dodatkową komplikacją był fakt, że część plemion arabskich została schrystianizowana przed narodzinami islamu. Jeśli dodamy do tego, że islam sięga do Starego i Nowego Testamentu, łatwo zrozumieć, że ofiary pierwszych najazdów arabskich często po prostu mogły nie wiedzieć, z kim (od strony religijnej) mają do czynienia.

Dlatego w źródłach chrześcijańskich Arabowie byli początkowo postrzegani jeszcze jako poganie, ale cześciej jako ci, którzy odrzucili politeizm. Autorzy chrześcijańscy pamiętali, że najeźdźcy przed islamem byli czcicielami bożków. Niektórzy twierdzili, że Mahomet nigdy nie porzucił tradycji swych przodków i tacy, którzy zarzucali mu ateizm.

Stopniowo zaczęto skłaniać się ku poglądowi, że islam jest herezją. Dostrzegano punkty wspólne chrześcijaństwa i islamu, ale i rozbieżności - dla monofizytów obce musiało być odrzucenie przez islam boskości Chrystusa ${ }^{240}$. W miarę zapoznawania się autorów chrześcijańskich z pismami muzułmańskimi zaczęto sobie uzmysławiać skalę różnic.

Stopniowo ocena islamu ewoluowała od traktowania go jako ,sekty Hagarenów" do uznania go za odrębną religię, konkurencyjną wobec chrześcijaństwa, złożoną z elementów zaczerpniętych z różnych źródeł, która wyrosła $\mathrm{z}$ idolatrii ${ }^{241}$. Mimo to chrześcijanie, zwłaszcza żyjący pod panowaniem muzułmańskim, starali się też znaleźć jakieś punkty wspólne z islamem - podkreślali np., że w Koranie znajdują się liczne odwołania do proroków ${ }^{242}$.

Równocześnie zmieniało się postrzeganie chrześcijaństwa przez muzułmanów. Początkowo to „ludzie Księgi”, bliscy islamowi, w miarę upływu czasu - wielki teologiczny i polityczny przeciwnik. W czasach Abbasydów wśród muzułmanów wzrosło zainteresowanie filozofią grecką. Kalifowie chcieli stworzyć nową ideologię, łączącą ludy zamieszkujące imperium ${ }^{243}$. Z punktu widzenia chrześcijan rodziło to niebezpieczeństwo synkretyzmu religijnego. Abu Kurra bardzo stanowczo odrzucał taką możliwość - mogła być tylko jedna prawdziwa religia ${ }^{244}$.

Odpowiedzią ze strony elit chrześcijańskich była próba zmierzenia się z muzułmanami na polu teologii. Nie zawsze jednak ich argumenty były tak naprawdę kierowane do wyznawców islamu. Równie często ich adresatami byli chrześcijanie, którym chciano dać do ręki broń, ułatwiającą obronę ich poglądów religijnych, i których starano się podtrzymać na duchu i zniechęcić do konwersji.

Różna była temperatura ocen islamu i polemik z nim. Teofanes przekazywał wiadomości na temat tej religii i jej twórcy spokojnie, unikając bardzo

${ }^{240}$ Por. Joachim Gnilka (Koran i chrześcijanie. Tajemnice poczatków, tłum. M. Waluś, Kielce 2010), który chce inaczej, ale to, co pisze pasuje raczej do nestorian.

${ }^{241}$ Por. The Early Christian-Muslim Dialog, s. 719.

${ }^{242}$ Por. Keating, Defending the „People of the Truth”, s. 9.

${ }^{243}$ Por. tamże.

${ }^{244}$ Por. Nassif, Religious Dialogue in the Eight Century, s. 336 i 339. 
emocjonalnych wyrażeń. Inaczej Jerzy Mnich, którego ponosiły emocje w jego tekście pełno pejoratywnych przymiotników, określających Mahometa, jego naukę i zwolenników ${ }^{245}$. Jan z Damaszku na ogół ograniczał się do umiarkowanych złośliwości, chociaż w pewnym momencie poniósł go temperament i oświadczył, że muzułmanie zamiast do raju trafią do „dusz osłów”, gdzie będą żyć jak bydło ${ }^{246}$. W kontekście powyższego trudno zgodzić się z sugestia, że Jan celowo nie używał prawdziwego imienia proroka, by nie narazić się na represje w związku z ubliżaniem $\mathrm{mu}^{247}$. Bartłomiej z Edessy był znacznie bardziej napastliwy, niż Jan, Niketas czy Al-Kindi. Pewne znaczenie miało miejsce, w którym żył polemista. Z pewnością pisząc w bezpiecznym Bizancjum można było sobie pozwolić na znacznie więcej, niż przebywając na terenie kalifatu. Abu Raitah al-Takriti starał się dać chrześcijanom narzędzie walki $\mathrm{w}$ polemice $\mathrm{z}$ muzułmanami ${ }^{248}$. Równocześnie unikał wszelkich odniesień do aktualnie rządzących i nie odnosił się do konsekwencji ich panowania.

\section{CHRISTIAN ELITES AND ISLAM (VII-X CENTURY)}

\section{(Summary)}

It is difficult to find equally important event in history as the birth of Islam and Arab expansion, although their importance was not appreciated at first. Its appearance was a breakthrough in several dimensions: religious, political, economic, cultural and lingual. The article attempts to discuss the reaction of Christian elites to the new monotheist religion.

Initially, Islam was not identified as a new, separate religion. It was believed that the invaders would be chased away soon. The invasion was perceived in the biblical context, as a punishment for sins and as a work of the devil. So thought Sophronios, Theodor, John of Nikiu. Other writers pointed out Jews and heretics as the cause of God's anger (Maximus the Confessor), but also emperor Constans (Anastasius the Synaite, Sebeos, some anonymous authors).

A debate between Christians and Muslims commenced when Muhammad was still alive and both parties knew virtually nothing of each other. With time, the knowledge about Islam increased, although it still depended on education, social status, place of residence and knowledge of Arabic. In the 8th century it became obvious that Muslim rule would continue which can be observed in the opinion expressed by such writers as Sebeos, Anastasios, Denys of Tell Mahré or Ghewond. The task of Christian elites then, was to survive in an alien, not in-

${ }^{245}$ Роr. Ю.В. Максимов, Георгий Амартол об Исламе, w: Византийские сочинения об Исламе, s. 66) doliczył się w jego tekście blisko setki epitetów.

${ }^{246}$ Por. Joannes Damascenus, De haeresibus 7, 39-41, SCh 383, 224, ŹMT 59, 139.

${ }^{247}$ Por. Żelazny, Patrystyczne świadectwa prób dialogu, s. 310.

${ }^{248}$ Por. Keating, Defending the „People of the Truth”, s. 31. 
frequently hostile environment and to preserve Christian faith. It was even more important when, particularly under the Umayyad rule, the religious policy became worse for Christians, which resulted in numerous conversions to Islam. The church must have felt threatened, consequently new arguments in the disputes with Muslims were needed. A form of a dialogue or polemics between two adversaries appeared. This can be seen in the texts of Theodor Abu Qurra, John on Damascus, in the polemics between patriarch Timothy with caliph Mahdi (781), homilies of a Syriac bishop from Iraq Mar Aba II (641-751), a discourse between monk Bert Hale and a wealthy Muslim or the answer of emperor Leo III to caliph Umar II (719), to mention just a few.

The Christians attacked primarily Muhammad himself. He was accused of being a heretic or fake prophet. His knowledge would come either from Jews or heretic Christians. His adversaries pointed out that he had not done miracles as Christ had. It was also said that his revelation had been nothing but his dream or a result of his illness (epilepsy), or even that he had been possessed by daemons.

Another target of attacks was the Quran, which was presented as a falsified Scripture. According to Niketas, it was not created by God, but by a daemon, as a compilation of many, often contradicting texts. It was also criticized as being non-original. Islam, was also be spread with the sword rather than with the word.

Key words: Byzantium, Islam, anti-islamic polemics, Muhammad, Quran.

Słowa kluczowe: Bizancjum, islam, polemika antyislamska, Mahomet, Koran.

\section{BIBLIOGRAFIA}

\section{Źródła:}

Andreas Salos, Apocalypsis, ed. and translated by L. Rydén: The Andreas Salos Apocalypse, DOP 28 (1974) 197-261.

Anastasius Sinaita, Sermo III, PG 89, 1152A-1180B.

Anonymus, Apologia Christianorum, ed. M. Dunlop Gibson, Studia Sinaitica VII, London 1889, 2-36 (przekład) i 74-107 (tekst arabski).

Arethas CAesariensis, Epistula ad ameram Damascenum, ed. L.G. Westerink: Arethae archiepiscopi Caesariensis scripta minora, vol. 1, Leipzig 1968, 233-245, lub ed. P. Karlyn-Hayter: Arethas's Letter to the Emir at Damascus, „Byzantion” 29-30 (1959/1960) 293-302. Przekład francuski A. Abel: La lettre polémique d'Arethas à l'émir de Damas, „Byzantion” 24 (1954) 355-370.

Bartholomaeus Edessenus, Elenchus et confutatio Agareni, PG 104, 1384A-1448A.

Bartholomaeus Edessenus (?), Contra Muhammed, PG 104, 1448B-1457D.

BukHARI: Translation of Sahih Bukhari - Islamic-English Book, transl. by M. Muhsin Khan, vol. 1, Book 1: Revelation, $\mathrm{nr}$ 6, https://archive.org/details/TranslationOfSahihAlBukhari-IslamicEnglishBook.pdf_509.

Colloquium Joannis patriarchae cum amero Agarenorum, éd. par F. Nau: Un colloque du patriarche Jean avec l'émir des Agaréens et faits divers des annés 712 à 716 , „Journal Asiatique" 11 (1915) nr 5, 268-271, przekład angielski: The Early Christian-Muslim 
Dialog. A Collection of Documents from the First Three Islamic Centuries (632- 900 A.D.), ed. N.A. Newman, Hatfield 1993, 24-28.

Doctrina Jacobi nuper baptizati, éd. et trad. par V. Deroche, commentaire par G. Dagron: L'Enseignement de Jacob, nouvellement baptisé, „Travaux et Mémoires” 11 (1991) 208-210.

EPHRAEM, Sermo de fine mundi, hrsg. und übersetzt von E. Beck: Des heiligen Ephraem des Syrers Sermones 3, CSCO 321, Scriptores Syri 139, Louvain 1972, 60-71 (tekst), 79-94 (przekład), lub hrsg. und mit Anmerkungen und Abhandlungen begleitet von C.P. Caspari: Briefe, Abhandlungen und Predigten aus den zwei letzten Jahrhunderten des kirchlichen Altertums und dem Anfang des Mittelaters, Christiania [Oslo] 1890, 208-220 (przekład łaciński).

Euthymius Zigabenus, Disputatio de fide cum philosopho saraceno in urbe Melitene, PG $131,20 \mathrm{C}-40 \mathrm{C}$.

Euthymius Zigabenus, Panoplia dogmatica ad Alexium Comnenum XXVIII: Adversus Saracenos, PG 130, 1332D-1360D.

JoAnnes Damascenus, De haeresibus, ed. R. le Coz : Jean Damascène, Écrits sur l'Islam, présentation, commentaire et traduction par R. Le Coz, SCh 383, Paris 1992, przekład polski A. Zhyrkova: Jan Damasceński, Dialektyka albo rozdziaty filozoficzne. O herezjach, ŹMT 59, Kraków 2011.

Georgius Monachus, Chronicon, ed. C. de Boor, vol. 2, Lipsiae 1904 = PG 110, 41A-1285D.

Ghewond Vardapetus, Historia, transl. by R. Bedrosian, New Jersey 2006 = www.tertullian.org/fathers/ghewond_01_history.htm.

Historia Patriarcharum, ed. ed. B. Evetts: History of the Patriarchs of the Coptic Church of Alexandria, PO 1/4, Paris 1948.

JoAnnes Niciensis, Chronica, transl. from Zotenberg's Ethiopic text by R.H. Charles: The Chronicle of John, bishop Nikiu, Text and Translation Society, London 1916

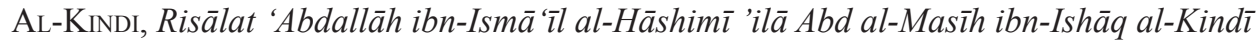
wa-risālat al-Kind̄̄ 'ilā al-Hāshimī, ed. tekstu arabskiego A. Tien, London 1880 (repr. 1885 i 1912), tekst wraz z przekładem hiszpańskim ed. F. González Muñoz: Exposición y refutación del Islam. La version Latina de las epistolas de al-Hāšimī y al-Kindī, Univ. da Coruña, Coruña 2005); przekłady - łaciński: Epistola Saraceni et Rescriptum Christiani, ed. J. Muñoz Sendino: Al-Kindi, Apologia del Cristianismo, „Miscellánea Comillas” 11-12 (1949) 375-460; włoski: Al-Kindi, Apologia del cristianesimo, traduzione dall'arabo, introduzione e cura di L. Bottini, Patrimonio di Cultura Arabo-Cristiana 4, Milano 1998; angielskie: W. Muir, The Apology of Al Kindy written at the Court of Al-Māmūn, New York 1887; The early Christian-Muslim dialogue. A collection of documents from the first three Islamic centuries (632-900 A.D.), trad. N.A. Newman, Hatfield (Pa.) 1993, 355-546 (tekst s. 381- 402 i 411-516); francuski: G. Pasteur Tartar, Dialogue islamo-chrétien sous le calife al-Mamun (813834). Les épitres d'al-Hashimi et d'al-Kindi, Paris 1985.

Al-Qur'ān, transl. A. Yusuf Ali: The Holy Qur'ān, Ware 2000, lub transl. A.Q. Qara'i: The Qur'ān with a Phrase-by-Phrase. English Translation, New York 2011, przekład polski z j. arabskiego J. Bielawski: Koran, Warszawa 1986. 
Leo VI Imperator, Epistula ad Omarum Saracenorum regem, ed. J.-P. Migne, PG 107, $315 \mathrm{~A}-324 \mathrm{~B}$.

Maximus Confessor, Epistula 14, PG 91, 533B-344C.

Michael Syrus, Chronica XI 8, éd. et trad. J.-B. Chabot, t. 2, Paris 1901.

Ibn Al-MunaĞĞIM, Risāla fì nubuwwat Muhammad, éd. S.Kh. Samir - P. Nwyia: Une correspondance islamo-chrétienne entre Ibn al-Munaggim, Hunayn ibn Ishāa et Qusțā ibn Lūqā, PO 40/4, Turnhout 1981, przekład polski J.A. Szymańczyk: Korespondencja między chrześcijaninem a muzułmaninem, tłum., ŹMT 36, Kraków 2005.

Nicetas Byzantinus, Confutatio dogmatum Mahomedis [vel] Confutatio falsi libri quem scripsit Mahomedes Arabs, PG 105, 669A-841C.

Nicetas Byzantinus, Refutatio epistulae regis Armeniae [vel] Confutatio et eversio epistulae ab Armeniae principe missae, PG 105, 588A-665C.

Nicetas Choniata, Thesaurus orthodoxae fidei XX 1-18, ed. J.-P. Migne, PG 140, 105A-121C.

Pseudo-Athanasius, Apocalypsis, éd. et transl. par F.J. Martínez: Apocalypse sahidique du Pseudo-Athanase, w: Eastern Christian Apocaliptic in the Early Muslim Period: Pseudo-Methodius and Pseudo-Athanasius, part 2, Washington 1985 [Ann Arbor University Microfilms], s. 285-411 (tekst koptyjski i arabski Apokalipsy), s. 462-555 (przekład).

Pseudo-Athanasius, Narrationes, éd. F. Nau: Le texte grec des récits du moine Anastase sur les saints Pères du Sinaï, OC 2:1902, 58-87; Le texte grec des récits utiles à l'âme d'Anastase (Sinaïte), OC 3:1903, 56-85; Le récits inédites du moine Anastase, „Revue de l'Institut Catholique de Paris" 1 (1902) 1-26; 2 (1902) 110-151.

Pseudo-Dionysius Telmahrensis, Chronica, publ. et trad. par J.-B. Chabot: Chronique de Denys de Tell-Mahré, 4e partie, Bibliothèque de l'École des Hautes Études. Sciences Historiques et Philologiques 112, Paris 1895, 1, lub ed. W. Witakowski: The Syriac Chronicle of Pseudo Dionisius of Tel Mahre, Studia Semitica Upsaliensia 9, Uppsala 1987.

Pseudo-Methodius, Apocalypsis (syriace), éd. et transl. par F.J. Martínez: Apocalypse syriaque du Pseudo-Méthode, w: Eastern Christian Apocaliptic in the Early Muslim Period: Pseudo-Methodius and Pseudo-Athanasius, (Phil. Diss.), part 1, Washington 1985, 58-92 (tekst) i 122-157 (przekład), lub ed. and transl. by B. Garstad: Apocalypse Pseudo-Methodius, Dumbarton Oaks Medieval Library 14, Cambridge (Mass.) - London 2012, 2-71 (wersja grecka), 74-141 (wersja łacińska), przekład polski A. Tronina: Apokalipsa Pseudo-Metodego, w: Apokryfy syryjskie, red. M. Starowieyski, Pisma Apokryficzne 6, Kraków 2011, 212-238.

ABū RĀ'ỊTAH, Risāla fì ithbāt dīn al-nașrāniyya wa-ithbāt al-thālūth al-muqaddas, ed. and transl. G. Graf, w: Die Schriften des Jacobiten Habīb Ibn Hidma Abū Rā ița, Habīb Ibn Khidma Abū Rā'ita, CSCO 130, 131-159 (tekst), CSCO 131, 159-194 (niemiecki przekład), Louvain 1951; lub ed. S.T. Keating: Defending the „People of the Truth" in the Early Islamic Period. The Christian Apologies of Abu Ra'itah, Leiden - Boston 2006.

Sebeos, Historia de Heraclio, traduite de l'arménien et annotée par F. Macler: Histoire d'Héraclius par l'évêque Sébeos, Paris 1904.

Sophronius Hierosolymitanus, Epistula synodica ad Sergium patriarcham Constantinopolitanum, PG 87/3, 3148A-3200C. 
Sophronius Hierosolymitanus, Homilia in Christi natalitia, hrsg. von H. Usener: Weihnatchspredigt des Sophronius, ,Rheinischen Museum” N.F. 41 (1886) 501-516.

Ali AL-TABARI, Al-radd 'ala al-Nașara, ed. I.-A. Khalifé - W. Kutsch: 'Ar-Radd 'alā-nNașārā de 'Alī at-Tabarī', "Mélanges de l'Université Saint Joseph” 36 (1959) 115 148, przekład francuski J.-M. Gaudeul: Riposte aux chrétiens par Ali al-Tabari, Roma 1995, przekład angielski N.A. Newman: The Early Christian-Muslim Dialog. A Collection of Documents from the First Three Islamic Centuries (632-900 A.D.), ed. N.A. Newman, Hatfield 1993, 568-657.

Theodorus Abucara, Opuscula ascetica [vel] Contra haereticos, Iudaeos et Saracenos varia opuscula, ed. J.-P. Migne, PG 97, 1461A-1601C.

Theophanes Confessor, Chronographia, ed. C. de Boor, vol. 1, Lipsiae 1883 (= Theophanes, Chronographia, rec. I. Classenus, vol. 1, CSHB 32, Bonnae 1839).

Timotheus Nestorianus, Apologia Christianorum, ed. and transl. by A. Mingana: Timothy's Apology for Christianity, w: Woodbrook Studies, vol. 2: Christian Documents in Syriac, Arabic, and Garshūni, Cambridge 1928, 1-162.

Visio Danielis (slavice), ed. by P.A. Lavrov: Apokrifičeskije teksty, Sbornik Otdeleniya russkogo yazyka i slovesnosti Imperatorskoi Akademii Nauk 67, Moskva 1899, thum. angielskie P.J. Alexander: Vision of the Prophet Daniel on the Emperors and the Last Days and the End of the World, w: P. Alexander, The Byzantine Apocalyptic Tradition, Berkeley - Los Angeles 1985, 65-72.

Vita Theodori Edesseni, ed. В.Г. Васильевский: Житие и жизнь иже во святых отияа нашего Феодора, архиепископа Едесского, „Православный Палестинскій Сборникъ" 4 (1886) nr 2, 264-265.

Abū 'İs̄̄ Al WARrāQ, Al-Radd 'alā l-thalāth firaq min al-Naṣārāa, ed. and transl. by D. Thomas: Anti-Christian Polemic in Early Islam, University of Cambridge Oriental Publications 45, Cambridge1992, 51-65 (Abū 'Is $\bar{a}$ al Warrāq's ,,Against the Trinity”) lub w: Early Muslim polemic against Christianity, ed. and transl. by D. Thomas, University of Cambridge Oriental Publications 59, Cambridge 2002, 60-82 (Abū ' $\bar{I}_{s} \bar{a}$ al Warrāq's ,,Against the Incarnation”).

\section{Opracowania}

Abel A., Le caractère sociologique du „,culte” de Mahomet dans l'Islam tardif, w: Mélanges Georges Smets, Bruxelles 1952, 43-55.

Alexander P.J., The Byzantine Apocalyptic Tradition, Berkeley - Los Angeles 1985.

Argyriou A., Perception de l'Islam et traductions du Coran dans le monde byzantine grec, „Byzantion” 75 (2005) 25-69.

Baнкоu A., The Christian Legend of Monk Bahīrā. The Syriac Manuscript of Mardin 259/2: Study and English Translation, http://www.baylorisr. org/wp-content/uploads/ bahkou_monk.pdf.

Bevan A., Mohammed's Ascension to Heaven, w: Studien zur semitischen Philologie und Religionsgeschichte Julius Wellhausen zum siebzigsten Geburtstag am 17. Mai 1914 gewidmet von Frenden und Schülern, hrsg. K. Marti, Beihefte zur Zeitschrift für die Alttestamentliche Wissenschafte 27, Giessen 1914, 51-61.

BRock S., Syriac sources for seventh-century history, „Byzantine and Modern Greek Studies" 2 (1976) 17-36. 
Brock S., Syriac Vievs of Emergent Islam, w: tenże, Syriac Perspectives on Late Antiquity, Collected Studies Series 199, London 1984, 9-21.

Brock S., Syriac Historical Writing: a Survey of the Main Sources, „Journal of the Iraqi Academy (Syriac Corporation)" 5 (1979/1980) 297-326 (= tenże, Studies in Syriac Christianity. History, Literature and Theology, Collected Studies Series 357, Aldershot 1992, 297-326.

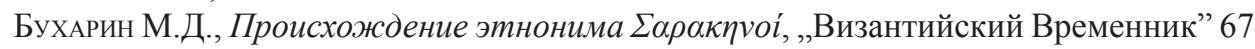
(92) (2008) 57-62

CAmeron A., The Literary Sources for Byzantium and Early Islam, w: La Syrie de Byzance à l'Islam: VII ${ }^{-}$-VIII ${ }^{e}$ siècles. Actes du Colloque international (Lyon - Paris, 11-15 septembre 1990), publiés par P. Canivet - J.-P. Rey-Coquais, Publications de l'Institut Français de Damas 137, Damas 1992, 3-14.

Christides V., Once again the „Narrations” of Nilus Sinaiticus, „Byzantion” 43 (1973) $37-50$.

Constantelos D. J., The Moslem Conquest of Near East as Reveated in Greek Sources of the VII th and the VIII ${ }^{\text {th }}$ Century, ,Byzantion” 42 (1972) 325-357.

Dick I., Un continuateur arabe de saint Jean Damascène, Théodore Abuqurra, évêque melchite de Harran. La personne et son milieu, cz. 1: Les études antérieures sur Abuqurra, POC 12 (1962) 209-223; cz. 2: Analyse des sources, POC 12 (1962) 319-332; cz. 3: Essai d'une esquisse historique, POC 13 (1963) 114-129.

Dick I., La discussion d'Abū Qurra avec les ulémas musulmans devant le calife alMa'mūn, ParOr 16 (1990-1991) 107-113.

Flori J., L'Islam et la fin des temps. L'interpretation prophetique des invasions musulmenes dans la chrétienté médiévale, Paris 2007.

Fuussin B., Démons et Sarrasins. L'auteur et le propos des Diègémata stèriktika d'Anastase le Sinaïte, „Travaux et Mémoires” 11 (1991), s. 381-409

Gerö S., The Legend of the Monk Bahīrā, the Cult of the Cross and Iconoclasm, w: La Syrie de Byzance à l'Islam: VII ${ }^{e}-V_{I I I}^{e}$ siècles. Actes du Colloque international (LyonParis, 11-15 septembre 1990), publiés par P. Canivet - J.-P. Rey-Coquais, Publications de l'Institut Français de Damas 137, Damas 1992, 47-58.

Gnilka J., Koran i chrześcijanie. Tajemnice poczq̨tków, thum. M. Waluś, Kielce 2010.

Grabar O., The Umayyad Dome of the Rock in Jerusalem, „Ars Orientalis” 3 (1959) 33-62.

GrIfFITH S.H., Disputes with Muslim in Syriac Christian Texts: From Patriarch John (d. 648) to Bar Hebraeus (d. 1286), w: Religionsgespräche im Mittelalter, hrsg. von B. Lewis F. Niewoehner, Wolfenbütteler Mittelalter-Studien 4, Wiesbaden 1992, 251-273.

Griffith S.H., Disputing with Islam in Syriac: the Case of the Monk Bēt Hālê and a Muslim Emir, „Hugoye. Journal of Syriac Studies” 3 (2000) nr 1, 1-19.

Griffith S.H., Reflections on the Biography of Theodore Abu Qurrah, ParOr 18 (1993) 143-170.

Griffith S.H., The Qur'an in Arab Christian Texts: the Developpement of an Apologetical Argument: Abu Qurrah in the Maglis of al- Ma'mun, ParOr 24 (1999) 203-233.

Griffith S.H., Theodore Abu Qurrah. The Intelectual Profile of an Arab Christian Writer of the First Abbasid Century, Tel Aviv 1992.

Grodzki M., ,"Muslims” and ,, islam” in Middle Eastern Literature of the Seventh and Eight Century AD, ,Studia Orientalia” 112 (2012) 1-16. 
Horowitz J., Die Muhammeds Himmelfahrt, „Islam” 9 (1919) 159-183.

Hoyland R.G., Seeing Islam as Others saw it. A Surway and evaluatuin of Christian, Jewish and Zoroastrian Writings on Early Islam, Princeton 1997.

Husseini S.L., Early Christian Explanations of the Trinity in Arabic in the Context of Muslim Theology, University of Birmingham Research Archive e-Theses Repository, Birmingham 2011, 77-141.

Jefrerey A., Gevond's Text of the Correspondence between 'Umar II and Leo III, HTR 37 (1944) 269-332.

Karczewski Ł., Dialog Teodora Abu Kurra ze światem islamu - zarys problematyki, „Seminare” 33 (2013) 277-292.

KaEgi W.E., Initial Byzantine Reactions to the Arab Conquest, w: The Expansion of the Early Islamic State, ed. F.M. Donner, The Formation of the Classical Islamic World 5, Aldershot 2008, 113-121 [pierwodruk: ChH 38 (1969) 139-149].

Keating S.T., Defending the „People of the Truth" in the Early Islamic Period. The Christian Apologies of Abu Ra'itah, Leiden - Boston 2006.

KenNedy H., Wielkie arabskie podboje. Jak ekspansja islamu zmienia świat, tłum. M. Wilk, Warszawa 2011.

Khoury A.-Th., Polémique byzantine contre l'Islam (VIII-XIII s.), Leiden 1972.

Khoury A.-Th., Les théologiens byzantins et l'Islam, t. 1: Textes et auteurs (VIII ${ }^{e}$-XIII ${ }^{e}$ siècle), Louvain - Paris 1969.

KościelniaK K., Dżihad. Święta wojna w islamie, Kraków 2006.

KościelniaK K., Grecy i Arabowie. Historia Kościoła melkickiego (katolickiego) na ziemiach zdobytych przez muzułmanów (634-1516), Kraków 2004.

KościelniaK K., Złe duchy w Biblii i Koranie, Kraków 1999.

Lammens H., Fatima et les filles de Mahomet, Rome 1912.

Lamoreaux J.C., Theodore Abu Qurrah and John the Deacon, GRBS 42 (2001) 361-386.

LAmoreaux J.C., The Biography of Theodore Abu Qurrah Revisited, DOP 56 (2002) 25-40.

Кривов М.В., Некоторые вопросы арабского завоевания Сирии и Палестины, „Византийский Временник” 46 (71) (1986) 88-99.

Madeyska D., Historia świata arabskiego. Okres klasyczny od starożytności do roku 750, Warszawa 1999.

МАксимов Ю.В., Варфоломей Эдесский об Исламе, w: Византийские сочинения об Исламе, отред. Ю.В. Максимова, Москва 2012, 86-91.

МАксимов Ю.В., Феодор Абу-Курра об Исламе, w: Византийские сочинения об Исламе, отред. Ю.В. Максимова, Москва 2012, 23-30.

Максимов Ю.В., Георгий Амартол об Исламе, w: Византийские сочинения об Исламе, отред. Ю.В. Максимова, Москва 2012, 65-67.

Meyendorff J., Byzantine Views of Islam, w: Arab-Byzantine Relations in Early Islamic Times, ed. M. Bonner, Ashgate 2004, $217-234$ [pierwodruk: DOP 18 (1964) 113-132].

Mikhail W.Y.F., 'Ammār al-Basrī’s Kitāb al-Burhān: A Topical and Theological Analysis of Arabic Christian Theology in the Ninth Century, University of Birmingham Research Archive e-Theses Repository, Birmingham 2013.

Muslim Perceptions of Other Religions: A Historical Survey, ed. J. Waardenburg, Oxford 1999. 
NAU F., Introduction, w: Un colloque du patriarche Jean avec l'émir des Agaréens et faits divers des annés 712 à 716, wyd. i thum. M.F. Nau, ,Journal Asiatique” 11.5 (1915) 230-232.

Nasry W., The Caliph and the Bishop. A 9th Century Muslim-Christian Debate: AlMa'mun and Abu Qurrah, Beyrouth 2008.

Nassif B.A., Religious Dialogue in the Eight Century, ParOr 30 (2005) 333-340.

Notн A., Problems of Differentiotion between Muslim and Non-Muslim: Re-reading the „, Ordinances od Umar”, w: Muslims and Others in Early Islamic Society, ed. R. Hoyland, Aldershot 2004, 103-124.

Pirenne H., Mahomet et Charlemagne, Paris 1937.

Platti E., La doctrine des chrétiens d'après Abū 'İsā al-Warrāq dans son traité sur la Trinité, „Mideo” 20 (1991) 7-30.

Pouzet L., Le hadith d'Héraclius: une caution byzantine à la prophétie deMuhammad, w: La Syrie de Byzance à l'Islam: VII ${ }^{-}$VIII ${ }^{e}$ siècles. Actes du Colloque international (Lyon - Paris, 11-15 septembre 1990), publiés par P. Canivet - J.-P. Rey-Coquais, Publications de l'Institut Français de Damas 137, Damas 1992, 59-65.

ReInink G., Pseudo-Methodius: A Concept of History in Response to the Rise of Islam, w: The Byzantine and Early Islamic Near East, Papers of the First Workshop on Late Antiquity and Early Islam, ed. A. Cameron - L.I. Conrad - G.R.D. Kind, Studies in Late Antiquity and Early Islam 1, t. 1, Princeton 1992, 149-187.

Reinink G., Political Power and Right Religion in the East-Syrian Disputation between a monk of Bēt Hālē and an Arab notable, w: The Encounter of Eastern Christianity with Early Islam, ed. E. Grypeou - D.R. Thomas - M. Swanson, The History of Christian-Muslim Relations 5, Leiden 2006, 153-169.

REInINk G. J., Early Christian Reactions to the Building of the Dome of the Rock in Jerusalem, w: tenże, Syriac Christianity under Late Sasanian and Early Islamic Rule, Collected Studies Series 831, Aldershot 2005, 227-241 (= „Христиансий Восток” 2(8) (2001) 227-241.

Roggema B., The Legend of Sergius Bahīrā. Eastern Christians Apologies and Apokalyptic in Responce to Islam, Leiden - Boston 2009.

SADOwSKI M., Chrześcijańska arabskojęzyczna literatura apologetyczna Bliskiego i Środkowego Wschodu w Okresie Abbasydów (750-1050), STHŚO 32 (2012) 87-106.

SAHAS D.J., John of Damascus on Islam: the „Heresy of the Ishmailites”, Leiden 1972.

SAmIR K.S., Une apologie arabe du christianisme d'époque umayyade?, ParOr 16 (19901991) 85-106.

SAmIR K.S., Prophet Muhammed seen through Arab Christian Eyes, w: Syrian Christians Under Islam: The First Thousand Years, ed. D.R. Thomas, Leiden 2001.

Savvides A.G.C., Some notes on the Term Agarenoī, Ismaelītai and Sarakenoi in Byzantine Sources, „Byzantion” 67 (1997) 89-96.

Schönborn C. von, Sophrone de Jérusalem, Vie monastique et confession dogmatique, Paris 1972.

Shahid I., Byzantium and the Arabs in the Sixth Century, t. I, cz. 1: Political and Military History, Washington 1995; t. I, cz. 2: Ecclesiastical History, Washington 1995.

SHaнid I., Byzantium and the Arabs in the Fifth Century, Washington 1989. 
Swanson M.N., Beyond Prooftexting: Approaches to the Qur'an in Some Early Arabic Christian Apologies, „The Muslim World” 88 (1998) nr 3-4, 297-319.

Thomas D., Abū 'Is $\bar{a}$ al Warrāq and the History of Religion, „Journal of Semitic Studies” 41 (1996) nr 2, 275-290.

Tolan J., Réactions chrétiennes aux conquêtes musulmanes. Étude comparée des auteurs chrétiens de Syrie et Espagne, „Cahiers de Civilisation Médiévale” 44 (2001) 350-352.

Tritton A.S., Caliphs and their Non-Muslim Subjects. A Critical Study of the Covenant of Umar, Delhi 2008.

Vasiliev A.A., Byzance et les Arabes, t. 2: La dynastie macédonienne, cz. 2: Extraits des sources arabes, trad. par M. Canard, Corpus Bruxellense Historiae Byzantinae 2/2, Bruxelles 1930.

Zhyrkova A., Wstęp, w: Jan Damasceński, Dialektyka albo rozdziały filozoficzne. O herezjach, tłum. A. Zhyrkova, ŹMT 59, Kraków 2011, 3-12.

ZiLio-Grandi I., La refutazione della profezia di Muhammad e del miracolo coranico di Qusta ib Luga, ParOr 22 (1997) 677-689.

ŻElazny J.W., Patrystyczne świadectwa prób dialogu między chrześcijanami a islamem, w: Wczesne chrześcijaństwo a religie, red. I.S. Ledwoń - M. Szram, Lublin 2012, 303-315. 
